\title{
THE GROWTH OF PARAMECIUM IN INFUSIONS OF KNOWN BACTERIAL CONTENT ${ }^{3}$
}

\author{
RUTH L. PHILLIPS
}

ONE FIGURE

CONTENTS

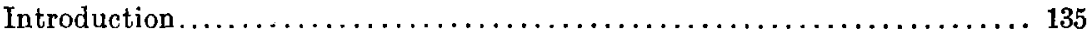

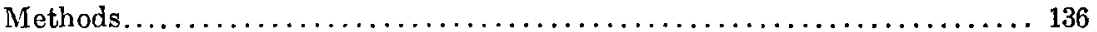

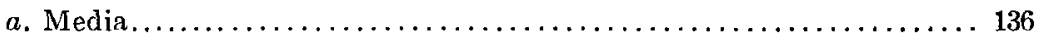

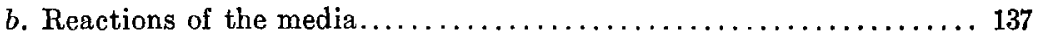

c. Isolation of the bacteria used for feeding Paramecium......... 138

d. Characteristics of these bacteria.......................... 139

e. Method used for growing Paramecium in pure cultures of bacteria. 143

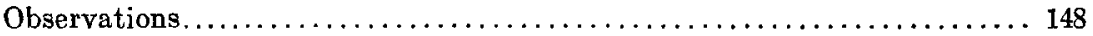

a. Growth of Paramecium aurelia in certain pure cultures of bacteria in 0.1 per cent standard timothy hay infusion............. 148

b. Behavior of Paramecium when fed upon pure cultures and mixtures, of the bacteria $A^{\prime}, B^{\prime}, C^{\prime}$, under varying experimental conditions. . 150

1. Behavior of Paramecium when fed upon pure cultures of bacteria $\mathrm{A}^{\prime}, \mathrm{B}^{\prime}, \mathrm{C}^{\prime}$, and the mixtures, $\mathrm{A}^{\prime} \mathrm{B}^{\prime}, \mathrm{A}^{\prime} \mathrm{C}^{\prime}, \mathrm{B}^{\prime} \mathrm{C}^{\prime}$, and $\mathrm{A}^{\prime} \mathrm{B}^{\prime} \mathrm{C}^{\prime}$, in 0.1 per cent standard timothy hay infusion from August 28,

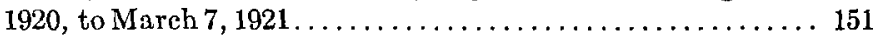

2. Change of food of Paramecium without change of medium .... 162

3 . Changing the medium without varying the food ............ 164

4. Change in medium accompanied by change in food.......... 168

5. The effect of sterile $\operatorname{media} \ldots \ldots \ldots \ldots \ldots \ldots \ldots \ldots \ldots \ldots \ldots$

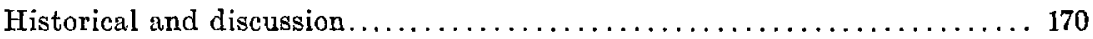

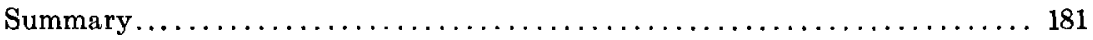

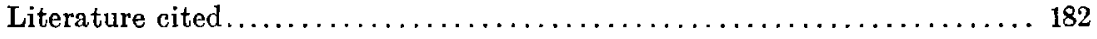

\section{INTRODUCTION}

The work of Hargitt and Fray ('17) on feeding pure lines of Paramecium with pure cultures of bacteria initiated a new phase in the investigation of protozoan metabolism. This work outlined the methods necessary for such a study and summarized the probable effect of pure cultures of bacteria, or mixtures of

${ }^{1}$ Contributions from the Zoological Laboratory, Liberal Arts College, Syracuse University; C. W. Hargitt, Director. 
several cultures, when used as food by Paramecium. However, these data were not extensive, and it has seemed worth while to carry the investigation further, in order to test the conclusions announced and to extend the experiments over a wider field.

Since food is so important a factor in the growth of animals and since the food of Paramecium is so variable, it would seem strange that so few investigations of this kind have been made, were it not that it is a difficult matter to treat adequately both the bacteriological and the protozoological sides of the subject. A complete analysis of the hay infusion would be very desirable, but the present knowledge of the saprophytic bacteria is so incomplete and the bacteriological work is so time-consuming, that it is impracticable for one person to carry it on together with the study of Paramecium in cultures of bacteria isolated from such infusions. The work described in this paper has accordingly been limited to a study of the continued growth of Paramecium aurelia in pure cultures and mixtures of the bacteria isolated from hay infusions or other infusions used for growing Paramecium.

I wish to express my thanks to Prof. George T. Hargitt, of the Department of Zoology, for his valuable suggestions and criticisms during this work; to Prof. Henry N. Jones, of the Department of Bacteriology, for suggestions and for the use of apparatus for the bacteriological investigations; to Miss Lucy J. Watt for the classification of the bacteria used in feeding experiments; to Mr. Clifton E. Halstead for the determination of the hydrogen ion concentrations of the media, and to Dr. Vasil Obreshkove for suggesting certain biometric methods.

METHODS

a. Media

Since the purpose with which this work was undertaken was to study the effect of food upon Paramecium, it was desirable that the media used be as uniform as possible. To secure such uniformity, a sufficient amount of each medium was made to last throughout the course of the experiments. These stock solutions were sterilized and set aside to be diluted as needed. Hargitt 
and Fray ('17) found that the high temperatures of the autoclave so altered the nature of the hay infusion that Paramecium could not live in it. For this reason, the three-day intermittent method of sterilization in the Arnold steam sterilizer has been used for all media in which it was desired to grow Paramecium. This method proved to be perfectly reliable.

The different infusions were prepared as follows:

1. The standard hay infusion of Jennings ('10) was made by allowing 10 grams of chopped timothy hay to boil for ten minutes in a liter of tap-water. This was cooled, brought up to volume with tap-water, filtered, and then sterilized in the Arnold for three successive days. From this stock infusion a 0.1 per cent solution was prepared from time to time as needed. The 0.1 per cent solutions were sterilized in a similar manner and used as the standard culture medium for inoculation with bacteria and for growing Paramecium.

2. An infusion was made from uncured swamp hay according to the formula used for the standard hay infusion. This with its 0.1 per cent solution was sterilized in the same way and put aside for further use.

3. Similarly, a third infusion was prepared from the common moneywort, Lysimachia nummularia L., which had been carefully dried and used at once without further curing.

\section{b. Reactions of the media}

The hydrogen ion concentrations of these three infusions were determined at the close of the experiments by Mr. Halstead according to the Gillespie ('20) drop method. The reactions were found to be as follows: For the 0.1 per cent standard timothy hay infusion $\mathrm{pH}=8.2$; for the 0.1 per cent uncured swamp hay infusion, $\mathrm{pH}=8.2$; for the 0.1 per cent moneywort infusion, $\mathrm{pH}=8.4$. Since the neutral point has been determined as $\mathrm{pH}=7$, increases over this point indicating alkalinity and decreases acidity, it will be seen that the reactions of these media were rather markedly alkaline. No attempt had been made to keep the reactions constant by the addition of buffers, so it is impossible to say what was the reaction of the media at the beginning of the work. 
A rough determination of the reaction of a watch-crystal culture in which Paramecium had been growing for a few days with the streptothrix $\mathrm{C}^{\prime}$ as food showed an increase in alkalinity over the sterile medium. Although the amount of fluid available was too small to determine the exact amount of this increase, the reaction obtained indicated that the presence of the organism $\mathrm{C}^{\prime}$ in hay infusion tends to increase the alkalinity of the medium. A similar test was made with a like amount of infusion in which Paramecium was living upon the bacterial mixture, $\mathrm{A}^{\prime} \mathrm{B}^{\prime} \mathrm{C}^{\prime}$. In this case the reaction tended to be more acid than the control sterile infusion. Whether this increase in acidity was due to the carbon dioxide excreted by a large number of Paramecia or to the reaction of the bacteria with the media or to a combination of these factors, it is impossible to say. It would seem that an investigation of the hydrogen ion concentrations of media used for cultivating Protozoa might be helpful in understanding some phases of the activities of these animals.

The fact that the hydrogen ion concentrations of the three types of media proved to be practically identical does not necessarily indicate a similarity in chemical constitution, and it is, I believe, safe to assume that they were chemically unlike. On this assumption it was, therefore, possible to vary the environment of Paramecium by the use of these different media as well as by changing the food.

\section{c. Isolation of the bacteria used for feeding Paramecium}

A little preliminary work demonstrated that a complete bacterial analysis of the hay infusion was impracticable in connection with an investigation of the reactions of Paramecium to food. It was, therefore, thought best to inoculate a sterile hay infusion in such a manner as to secure the types of bacteria ordinarily found in the hay infusions used for growing Paramecium in the laboratory. This was done with all precautions necessary to exclude bacteria from sources other than hay.

Agar plates were poured and inoculated from the infusions every day for the first three days, and again at the end of nine 
days when the initial rapidity of bacterial growth had somewhat subsided. In order to secure bacteria from an old culture supposedly unfavorable to Paramecium, plates were made from a laboratory culture from which the pure lines of Paramecium used in this work were taken, but in which, for some reason, the animals were no longer abundant. The usual technique for making bacterial plates was followed, and only such colonies selected as were predominant on the plates after they had remained at laboratory temperature for forty-eight hours. It is believed that the bacteria secured in this way were fairly representative of those which furnish the bacterial food of Protozoa introduced into such an infusion. Pure cultures of the bacteria from the predominating colonies were grown upon agar slants in the usual way and served as the source of the material used in testing the behavior of Paramecium with reference to its food. That these bacteria were representative of those occurring in fresh, middle-aged and old infusions may be safely assumed.

\section{d. Characteristics of the bacteria used for feeding Paramecium}

When Miss Watt attempted to classify the bacteria used in these experiments, she found, as did Hargitt and Fray, that these saprophytic forms are very difficult to identify positively. The classification of Chester ('14) proved more satisfactory for this investigation than the more recent work of the Society of American Bacteriologists (Winslow, '20). Chester's classification is based upon reactions with media as well as morphological characteristics, and the classification of the American Society of Bacteriologists lacks completeness in this respect. Neither work is satisfactory in classifying saprophytic bacteria beyond genera; species, therefore, have not been given except tentatively in one or two cases. The organisms have been placed in groups according to their reactions with media, and each organism has been given the letter used in the experimental work.

With the exception of one group of bacteria, the organisms used in the feeding experiments were isolated from infusions which had been inoculated from hay or actually used for growing Paramecium. One set of experiments was undertaken in which 
the organisms used for food were B. coli, B. cereus, and B. proteus. These were chosen because of the common occurrence of B. coli in bodies of water in which Paramecium is found in nature, and because $B$. cereus and $B$. proteus are such frequent saprophytes and might, therefore, be expected to be occasional components of the food of Paramecium. The pure cultures of these organisms were obtained from the laboratory stock of the Department of Bacteriology. The following descriptions of the bacteria used include such features as morphology, nature of the agar colonies, staining reactions, and reactions with various media. These features should be an aid to one who wishes to work with such bacteria in determining whether the types he has isolated are the same as those here described. It is fully realized that with the present lack of detailed knowledge of the saprophytic bacteria, such a description can only be an aid in identification and cannot be considered as a key to these types of bacteria.

Indol formation could not be determined, owing to trouble with the reagents.

Organism A. Belongs to Bacterium class III, group II, the Rhinosclermatis group of Chester. Isolated from a one- to three-day hay infusion.

Morphology: short rod, nearly spherical, grows in chains, nonmotile.

Agar colonies: round, moist, glistening, granular, edge sharply defined and broadly lobed as in colon type, non-chromogenic.

Staining reactions: capsulated, pleomorphic, show bipolar staining, Gram negative.

Gelatin: not liquefied, growth uniform, line of puncture beaded.

Litmus milk: neutral to slightly alkaline.

Bouillon: sediment at bottom, cloudy.

Dextrose bouillon: no acid, no gas, heavy membrane at bottom, cloudy.

Lactose bouillon: no acid, no gas, slight sediment at bottom, cloudy.

Saccharose bouillon: no acid, no gas, cloudy.

Mannite bouillon: no acid, no gas, cloudy.

Organism B. Did not grow well after the first few transfers, and died before the characteristics could be determined.

Organism C. Belongs to class $\mathrm{XV}$, group II $\mathrm{B}$, the subtilis group of Chester. Isolated from a nine- to fourteen-day hay infusion.

Morphology: short rod, some short chains noted, endospores central, markedly motile. 
Agar colonies: amoeboid, spreading, smooth, glistening, growth rapid, non-chromogenic.

Staining reactions: Gram positive. villous.

Gelatin: rapidly liquefied, sacculate, growth best at top, plumose to

Litmus milk: slightly decolorized at bottom of tube after four days, slowly becoming entirely decolorized, completely peptonized after thirty days.

Bouillon: pellicle formed.

Dextrose bouillon: no acid, no gas, membrane formed.

Lactose bouillon: no acid, no gas, membrane formed.

Saccharose bouillon: no acid, no gas, membrane formed.

Mannite bouillon: no acid, no gas, flaky sediment at bottom.

Organism J. Belongs to class VIII, B. subflavus type of Chester.

Isolated from a one- to three-day hay infusion.

Morphology: short rod, almost spherical, markedly motile.

Agar colonies: compact, slight tendency toward radiation, slightly chromogenic, yellow.

Staining reactions: capsulated, Gram positive.

Gelatin: not liquefied, growth spreading over top, growth best at top, filiform, beaded along edge.

Bouillon: clear, membrane at top.

Dextrose bouillon: no acid, no gas, membrane present, flocculent sediment, medium later becomes cloudy.

Lactose bouillon: no acid, no gas, membrane present, flocculent sediment, medium later becomes cloudy.

Saccharose bouillon: no acid, no gas, membrane present, flocculent sediment, medium later becomes cloudy.

Mannite bouillon: no acid, no gas, membrane present, flocculent sediment, medium later becomes cloudy.

Organism K. Class IV of Chester. A micrococcus. Isolated from a one- to three-day hay infusion.

Morphology: small spheres, may occur in chains, cells vacuolated, non-motile.

Agar colonies: grow slowly, moist, edge sharply defined, non-chromogenic.

Staining reactions: Gram positive.

Gelatin: no liquefaction after eleven days, growth uniform and filiform.

Litmus milk: becomes slowly alkaline, slightly decolorized, slightly peptonized, later is completely decolorized and peptonized.

Bouillon: clear.

Dextrose bouillon: no acid, no gas, cloudy.

Lactose bouillon: no acid, no gas, cloudy with sediment.

Saccharose bouillon: no acid, no gas, cloudy, heavy sediment.

Mannite bouillon: no acid, no gas, cloudy with small colonies scattered throughout the medium, cloudiness slowly disappears to be replaced by sediment. 
Organism $L$. Class XV, group II B, the subtilis group of Chester. Isolated from a nine- to fourteen-day hay infusion.

Morphology: long rods, sometimes single, sometimes in chains of two, endospores central, motile.

Agar colonies: round, moist, glistening, edge sharply defined, slightly indented, granular, non-chromogenic, medium strongly discolored, brown.

Staining reactions: Gram positive.

Gelatin: liquefied rapidly, growth sacculate, filiform.

Litmus milk: initial coagulation followed by decolorization and peptonization.

Bouillon: flocculent cloudiness.

Dextrose bouillon: no acid, no gas, pellicle at top.

Lactose bouillon: no acid, no gas, pellicle at top.

Saccharose bouillon: no acid, no gas, pellicle at top.

Mannite bouillon: no acid, no gas, growth cloudy, especially below membrane.

Organism $A^{\prime}$. Bacterium class VI, group II, of Chester, possibly B. Luteum. Isolated from a nine- to fourteen-day hay infusion.

Morphology: small rods, non-motile.

Agar colonies: round, convex, moist, opaque, edge slightly irregular, chromogenic, deep yellow. tive.

Staining reactions: dark staining granules at one end, Gram posi-

Gelatin: no liquefaction at first, liquefied after two months, growth best at top, yellow, filiform.

Litmus milk: slightly alkaline at first, slowly decolorizing and peptonizing.

Bouillon: yellow pellicle at top, medium fairly clear with flocculent sediment.

Dextrose bouillon: no acid, no gas, slight pellicle.

Lactose bouillon: no acid, no gas.

Saccharose bouillon: no acid, no gas.

Mannite bouillon: no acid, no gas.

Organism B'. Class VII, group II, of Chester, possibly B. latericium or B. havaniensis. Isolated from an old culture in which Paramecium were not at the time thriving.

Morphology: short rod, non-motile.

Agar colonies: very slow growing, round, moist, raised, opaque at center, edge indefinite, chromogenic, brick red.

Staining reactions: Gram negative.

Gelatin: not liquefied, growth best at top, spreading, beaded along line of stab.

Litmus milk: neutral at first, followed by decolorization and alkalinity.

Bouillon: red sediment, red growth at top.

Dextrose bouillon: no acid, no gas, flocculent sediment, red growth at top. 
Lactose bouillon: no acid, no gas, red growth at top.

Saccharose bouillon: no acid, no gas, red growth at top.

Mannite bouillon: no acid, no gas, red growth at top and red sediment.

Organism $C^{\prime}$. A streptothrix belonging to group II, Streptothrix of Chester. Isolated from a nine- to fourteen-day hay infusion.

Morphology: long filaments, fruiting bodies produced by multiple division of a filament, unbranched.

Agar colonies: myceloid, aerial hyphae formed, edge not welldefined, growth rather slow, chromogenic, shell pink, color easily lost.

Staining reactions: Gram negative.

Gelatin: liquefies very slowly, becoming evident after two months, growth slow over top and along line of stab where it is villous with radiatingly extending processes.

Litmus milk: alkaline and slowly peptonizing.

Bouillon: growth flaky.

Dextrose bouillon: no acid, no gas, membrane at top which drops to bottom if shaken, flocculent sediment.

Lactose bouillon: no acid, no gas, growth granular with round colonies gathered at top.

Saccharose bouillon: no acid, no gas, growth granular with round colonies gathered at top.

Mannite bouillon: no acid, no gas at first, but showing tendency to gas formation beneath the membrane which forms at the top.

Organism $J^{\prime}$. B. coli. Isolated from a laboratory stock culture.

Organism $K^{\prime}$. B. cereus. Isolated from a laboratory stock culture.

Organism $L^{\prime}$. B. proteus. Isolated from a laboratory stock culture.

\section{e. Method used for growing Paramecium in pure cultures of bacteria}

It is obvious that if we are to cultivate Paramecium in pure cultures of bacteria, the animals must first be rendered bacteriafree, and the cultures must be so handled as to exclude contamination with foreign bacteria throughout the course of the experiments. Hargitt. and Fray ('17) devised a method for freeing Paramecium of bacteria by washing the animals individually with sterile water in depression slides placed in Petri dishes. The Petri dishes also served as moist chambers in which the animals could be grown and observed without danger of contamination. Their results show that depression slides are better than ordinary watch-crystals for washing, and that they could rely upon five successive washings for sterilizing a given animal. 
Their method is undoubtedly reliable, for their tests were thorough and showed that no bacteria would be carried over by the animal after the last washing, thus excluding the contamination of pure cultures of bacteria from this source. This method was modified by using small watch-crystals, 1 inch in diameter, in place of depression slides. From five to seven of these can be easily baked in a single Petri dish. Five was the number used for carrying the cultures from day to day, whereas seven were employed for washing each animal. These watch-crystals were kept from slipping about by asbestos mats cut so as to fit exactly the bottom of a Petri dish. Each mat was perforated with as many holes as there were watch-cyrstals to be placed in the moist chamber. In this way the individual cultures were secured from slipping, and the entire apparatus could be baked repeatedly. The asbestos, furthermore, served as a sponge to keep the air within the Petri dishes moist.

The use of this apparatus made it necessary to wash each animal seven times instead of five, but this slight disadvantage was so outweighed by the advantages of the method that it was employed throughout the course of the work. A further change in the method of Hargitt and Fray consisted in the use of sterile 0.1 per cent standard hay infusion for washing the Paramecia instead of sterile water. The infusion is easily kept in stock, and its use as a washing fluid lessens the danger of injury during the sterilizing process by avoiding a change of medium at this time.

The pipettes used in handling the Paramecia were made by drawing out soft glass tubing to capillary fineness. The tip of each was annealed so that an animal coming in contact with it would not be injured. The upper end of each pipette was plugged with cotton to prevent contamination with the bulbs which were not sterilized. A large number of these pipettes was kept on hand, and a fresh one used for the transfer of each animal from one watch-glass to another. Mason jars were found more convenient holders than the ordinary pipette boxes, which were too long. These jars with their contents were carefully baked before using and, in addition to this, each pipette was carefully flamed before it was introduced into a culture fluid. 
The efficiency of this method of washing was tested by plating the contents of each watch-crystal within a washing chamber. It was found that the process of plating could be simplified by pouring the agar directly into the watch-crystals. In this way exceedingly striking demonstrations of the efficiency of the method were secured. It was possible to determine the exact point at which the animals became free from bacteria by absence of colonies on these miniature plates. Thorough testing of this method showed that while colonies would not be present after from three to five washings, it was not safe to rely upon this number, for if the animal were plated with the washing fluid of the fifth plate, an occasional colony would sometimes develop. This did not occur after the sixth or seventh washing, and repeated trials convinced me that seven washings could be relied upon to free Paramecium aurelia from bacteria.

The animals were grown in pure cultures of bacteria or in mixtures of such cultures in Petri-dish moist chambers containing five watch-crystal cultures as just described. The safety of such a method was completely demonstrated by the tests made while these cultures were under observation. The method employed was to take samples of the fluid from each watch-crystal of a group of five, dilute these with sterile tap-water, and plate in the usual way. These plates were allowed to develop at room temperature for from three to four days according to the temperature of the laboratory. In this way it was possible to know whether sufficient contamination was occurring to make rewashing the animals necessary. An occasional foreign colony was not considered evidence of serious contamination, since the great mass of bacteria would still be of the original stock.

Since tests at intervals as great as thirty days showed no evidence of serious contamination, it is probable that it is not necessary to wash the animals more frequently. However, in actual practice it was customary to wash them as often as every three or four weeks, in order to be absolutely sure that contamination was being kept out of the cultures. It is interesting to note that a test made after actual observation of the cultures had been discontinued, and the great care in handling lessened, 
showed a rather remarkable freedom from contamination after an interval of forty-six days. One of the bacterial mixtures showed complete absence of contamination when tested by plating at this time. These tests demonstrate that it is perfectly possible to avoid undue contamination of pure cultures of bacteria used for feeding Paramecium, and that it is even possible to do this for some time without particular care. In practical work, however, one should always flame each pipette carefully before it is used, and take every possible precaution by sterilizing all media and glassware.

The Paramecia used in all feeding experiments were isolated from a laboratory culture rich in both Paramecium aurelia and caudatum. Paramecium aurelia was chosen because of the greater ease with which it can be handled in small amounts of culture fluid. The usual method of growing pure-line cultures was employed, and stock lines were kept in vials of hay infusion.

Perfectly fresh cultures of bacteria for feeding were secured by inoculating small vials of sterile 0.1 per cent infusions with pure cultures of bacteria. This was done each day, so that a series of bacterial cultures, each twenty-four hours old at the time of using, was obtained. Such cultures insured vigorous, rapidly growing bacteria, and were as free as possible from an accumulation of bacterial decomposition products. Mixtures of these cultures were made as desired in the watch-crystals in which the Paramecia were to be grown. By making the mixtures in this way instead of allowing the bacteria to grow in mixed culture in the vials of infusion, the possibility of unfavorable reactions of the bacteria with one another was reduced to the minimum.

Workers with infusions of unknown bacterial content have supposed that the bacteria carried over in transfer of a Paramecium to fresh medium would provide an ample supply of food. This assumption appears to have been justified. It was desired to use infusions of this sort as controls, but it seemed that this method might allow the gradual introduction of harmful bacteria and that the decline so frequently noted in the vitality of cultures of Paramecium might be due to such a change of food. To avoid this possibility in the chance mixtures, hay infusion was inocu- 
lated with a portion of a head of timothy hay every day and used when twenty-four hours old, thus securing fresh cultures of bacteria on the hay. It was believed that in this way a chance mixture of bacteria would be secured which would be more comparable to that of the fresh infusions in which Paramecia thrive best when grown in mass culture. It turned out in actual practice that this assumption was probably incorrect. Infusions seeded in this way were excellent for the growth of Paramecium for four months. After this the division rate sharply declined and the death rate increased until the lines in this mixture died, and it was impossible to replace them. The possibility is suggested that the actual change in the bacterial content of the chance mixture was greater than if dependence had been placed upon inoculation with bacteria carried over with the Paramecia. This failure of the chance mixture could not have been foretold during the course of the experiments, since its behavior up to the actual time of death of the animals was not unlike that of certain of the cultures of known bacterial content. Because of the failure of this chance mixture during the latter part of the work, the culture $\mathrm{C}^{\prime}$ was used as the control, the chance mixture serving as an additional index during the time it was furnishing adequate food. This line $\mathrm{C}^{\prime}$ was chosen as the control because of its uniform behavior throughout the course of the observations, and because it was a component of all infusions of known bacterial content used during this time, save in those cases where it was desired to make a complete change of food.

From five to ten lines of Paramecium were grown in each culture of known bacterial content. An equal number of animals were grown in the chance mixture. Daily transfers were made to fresh fluid except in a few cases during the winter when the temperature of the laboratory was so low that bacteria would not grow rapidly enough to furnish a good medium. But a single animal was carried over in each transfer, so that a new series of cultures was started each day. Contamination from the air during these transfers was avoided by raising the cover of the Petri dish only enough to admit the passage of a carefully flamed capillary pipette. Since it was not deemed necessary to wash 
the animals more frequently than every few weeks, the only precautions taken against contamination with foreign bacteria in the daily transfer were those which insured sterile glassware and sterile media and avoidance of air-borne bacteria during transfer. This procedure enabled me to keep accurate daily records of at times as many as eighty cultures without infringing upon the routine of other work.

Careful record of the rate of division was kept, and each death noted, as it was considered important to have a record of the death rate as well as the rate of fission in determining the effect of food upon the animals. Previous work of Woodruff ('11) has established the fact that one may disregard the effect of light, ordinary ranges of temperature, and barometric pressure in such experimental work as this. It was, therefore, not considered necessary to keep records of these features.

A series of tables was compiled from the daily records by averaging for three-day intervals. The very minor fluctuations in division rate which appear in the daily observations, and which depend so much upon the personal equation of the observer, disappear when the three-day intervals are used; but the five-day interval, which was also tried, causes too much removal of small differences in rate of fission for a thorough study of changes in metabolism due to the influence of food. The tables show the average number of divisions for the time covered by a given set of observations, the percentage of high divisions, the percentage of low divisions, and the percentage of deaths. These percentages were found to be helpful in the interpretation of results. The graphs were made from tables in which the averages were computed for the three-day intervals.

\section{OBSERVATIONS}

a. Growth of Paramecium aurelia in certain pure cultures of bacteria in 0.1 per cent standard timothy hay infusion

Nine pure cultures of bacteria and twelve mixtures of these were fed at different times to pure lines of Paramecium. These bacteria have already been described as to cultural characteris- 
tics, and the letters given in this description will be used in the following account.

During the period from August 18 to August 27, 1920, the bacteria $\mathrm{A}, \mathrm{B}$, and $\mathrm{C}$ were fed in pure cultures and in the mixtures $\mathrm{AB}, \mathrm{AC}, \mathrm{BC}$, and $\mathrm{ABC}$. $\mathrm{A}$ chance mixture made by inoculating sterile infusion with timothy hay was used as a control. The letter $\mathrm{M}$ has been given to this type of mixture throughout the description of the feeding experiments.

The average division rate for $M$ for the entire period was taken as the mean from which the percentages of high divisions, low divisions, and deaths were computed. Percentages of mean and zero divisions do not appear to be of any great help in interpreting results, and have, therefore, been omited from all accounts and tables which follow. Throughout this account the term 'interval' is employed to indicate the short groups of three days which were used in computing the averages of division rates, etc., whereas the term 'period' is applied to the longer durations of time during which the animals were subjected to a given set of conditions. Woodruff ('11) has defined a rhythm as "a minor rise and fall of the fission rate, due to some unknown factor in cell metabolism from which recovery is autonomous." It is in this sense that the term is used in this paper.

The bacteria A, B, C and their mixtures proved to be unsatisfactory food for Paramecium. In no case did the division rate exceed 1.5. The death rate was high in all save $\mathrm{A}$, and it was impossible to get an active metabolism by the use of these bacteria in pure culture or in mixtures. Meanwhile, the control, M, maintained a high metabolic rate.

On August 22, 1920, feeding with the pure cultures, J, K, L, and the mixtures JK, JL, KL, and JKL, was started. This group of cultures was under observation until August 31, 1920, during which time the result was comparable to that gained in attempting to feed A, B, and C. Although the results of feeding mixtures were slightly better than those obtained by the use of pure cultures, the slight advantage thus gained could not be continued, and the animals eventually died. 
A third series of cultures was started on September 3, 1920, with the bacteria $J^{\prime}, K^{\prime}, L^{\prime}, J^{\prime} K^{\prime}, J^{\prime} L^{\prime}, K^{\prime} L^{\prime}$, and $J^{\prime} K^{\prime} L^{\prime}$ as food. The bacteria $\mathrm{J}^{\prime}, \mathrm{K}^{\prime}$, and $\mathrm{L}^{\prime}$ were $\mathrm{B}$. coli, B. cereus, and B. proteus respectively. These organisms were unsatisfactory as food. One hundred per cent of deaths occurred during the first interval with $L^{\prime}$ (B. proteus) as food, and the same result took place when $K^{\prime}$ (B. cereus) was added to $L^{\prime}$. The addition of $J^{\prime}$ to the mixture seemed to prevent this total mortality.

The results of feeding these three groups of bacteria in pure culture seem to support the contention of Hargitt and Fray ('17) that pure cultures of bacteria, as a rule, do not prove to be satisfactory food for Paramecium. The ability of one type of bacterium to neutralize the harmful effect of another, as illustrated by the combination of $J^{\prime}$ with $L^{\prime}$, and the stimulating effect of combining bacteria are interesting problems raised in this work. Reactions of this type will be pointed out as they occur, leaving their analysis for future investigation. The outstanding result of these preliminary experiments, in which nine pure cultures of bacteria were used and twelve combinations of these cultures, is that in no case were they able to maintain the life of Paramecium more than a few days. Moreover, of those cultures which did sustain the life of the animals for a few days, none were able to produce a normal rate of metabolism, and were, therefore, very unsatisfactory food.

b. Behavior of Paramecium aurelia when fed upon pure cultures, and mixtures, of the bacteria $A^{\prime}, B^{\prime}, C^{\prime}$ under varying experimental conditions

On August 28, 1920, feeding was started with the bacteria $\mathrm{A}^{\prime}, \mathrm{B}^{\prime}, \mathrm{C}^{\prime}$ and the mixtures $\mathrm{A}^{\prime} \mathrm{B}^{\prime}, \mathrm{A}^{\prime} \mathrm{C}^{\prime}, \mathrm{B}^{\prime} \mathrm{C}^{\prime}, \mathrm{A}^{\prime} \mathrm{B}^{\prime} \mathrm{C}^{\prime}$. Observations were continued upon certain of these lines until March 7 , 1921, with only such interruptions as the experimental conditions demanded. The original pure lines of Paramecia with which this series of experiments was conducted was still in existence in the mixed food $\mathrm{A}^{\prime} \mathrm{B}^{\prime} \mathrm{C}^{\prime}$ and in the pure culture $\mathrm{C}^{\prime}$, on June 2, 1921. Although neither $A^{\prime}$ nor $B^{\prime}$ proved to be satisfactory when fed in pure culture, they were exceptionally well adapted 
to this particular line of Paramecium when fed in combination with $\mathrm{C}^{\prime}$, with the exception of $\mathrm{B}^{\prime} \mathrm{C}^{\prime}$. During the course of the work with these organisms, the chance mixture $\mathrm{M}$ failed to provide suitable conditions for the life of Paramecium. The records for $M$ will be given, but after careful consideration, it has seemed best to take the culture $\mathrm{C}^{\prime}$ as a control for the entire series of observations. $\mathrm{C}^{\prime}$ showed greater uniformity in metabolic rate throughout the entire time than any other culture and is particularly well fitted to serve as an index for comparing the effect of feeding Paramecium with the other bacteria of this group. The chance mixture $M$ serves as an additional index during the time when it was supplying an adequate food.

The tables which follow show the averages for the entire time from August 28, 1920, to March 7, 1921, and for the separate periods included in this time. The observations have included a variety of experimental conditions. These were, 1), the behavior of Paramecium when fed upon the bacteria in pure culture and in mixtures in 0.1 per cent standard timothy hay infusion during the entire length of time from August to March; 2) the effect of change in food without changes in medium; 3 ) the effect of changes in medium without changes in food; 4 ) the effect of changes in food and medium; 5) the effect of sterile media uncombined with food. It would be interesting to add to these another condition, namely, the feeding of dead bacteria of known types in sterile infusions. These various experimental conditions will be described in the order given.

1. The behavior of Paramecium when fed upon pure cultures of the bacteria $A^{\prime}, B^{\prime}, C^{\prime}$ and the mixtures $A^{\prime} B^{\prime}, A^{\prime} C^{\prime}, B^{\prime} C^{\prime}$, and $A^{\prime} B^{\prime} C^{\prime}$ in 0.1 per cent standard timothy hay infusion from A ugust 28, 1920, to March 7, 1921. The results obtained during this time are summarized in table 1 . In addition to the averages of the division rates and percentages of high divisions, low divisions, and deaths, the number of days each line was under observation is given. Differences in duration of the observations of $\mathrm{A}^{\prime} \mathrm{C}^{\prime}$ and $\mathrm{A}^{\prime} \mathrm{B}^{\prime} \mathrm{C}^{\prime}$ are due to the fact that, owing to the time necessary for washing the animals, it was not possible to start all lines at once. In the case of the chance mixture, $M$, the shorter time is due to 
the failure of this mixture to support the life of Paramecium during the last two months of the observations. The mean division rate for $\mathrm{C}^{\prime}, 1.033$, is somewhat lower than is characteristic for Paramecium aurelia when living under favorable conditions. It was therefore thought best to take the mean rate for M, 1.444, as the basis for computing the various percentages.

An examination of table 1 confirms the evidence of the preliminary experiments, namely, that Paramecium does not ordinarily thrive upon pure cultures of bacteria. That it may sometimes do so is evident from the results of feeding with the

TABLE 1

Summary of the results of feeding Paramecium with the bacteria, $A^{\prime}, B^{\prime}, C^{\prime}$, the mixtures $A^{\prime} B^{\prime}, A^{\prime} C^{\prime}, B^{\prime} C^{\prime}$, and $A^{\prime} B^{\prime} C^{\prime}$, and the chance mixture $M$, from August 28, 1920, to March 7, 1921

\begin{tabular}{|c|c|c|c|c|c|}
\hline FOOD & $\begin{array}{c}\text { AVERAGE } \\
\text { NUMBER DAILY } \\
\text { DIVISIONS }\end{array}$ & $\begin{array}{l}\text { PER CENT HIGH } \\
\text { DIVISTONS }\end{array}$ & $\begin{array}{l}\text { PER CENT LOW } \\
\text { DIVISIONS }\end{array}$ & $\begin{array}{l}\text { PER CENT OF } \\
\text { DEATH }\end{array}$ & NUMBER DAYS \\
\hline$A^{\prime}$ & 0.6 & 0 & 37.5 & 31.2 & $3^{1}$ \\
\hline $\mathrm{B}^{\prime}$ & 0.333 & 0 & 18.2 & 45.5 & $4^{1}$ \\
\hline $\mathrm{C}^{\prime}$ & 1.033 & 18.3 & 36.3 & 5.2 & 130 \\
\hline $\mathrm{A}^{\prime} \mathrm{B}^{\prime}$ & 1.175 & 11.8 & 17.6 & 29.4 & $3^{1}$ \\
\hline $\mathrm{A}^{\prime} \mathrm{C}^{\prime}$ & 1.793 & 40.3 & 33.7 & 3.3 & 131 \\
\hline $\mathrm{B}^{\prime} \mathrm{C}^{\prime}$ & 1.305 & 37.2 & 26.4 & 11.8 & $27^{2}$ \\
\hline$A^{\prime} B^{\prime} C^{\prime}$ & 1.530 & 29.2 & 35 & 7.6 & 127 \\
\hline $\mathbf{M}$ & 1.444 & 22.4 & 39.7 & 9.5 & 92 \\
\hline
\end{tabular}

${ }^{1}$ Died at end of time designated.

2 Discontinued because unsatisfactory.

streptothrix $\mathrm{C}^{\prime}$. This organism was used with good effect for a period covering six and one-half months. Nor should it be forgotten that Paramecia from this line were doing well in pure cultures of $\mathrm{C}^{\prime}$ on June 2, 1921-a total of over nine months.

A transitory stimulating effect on Paramecium was had by combining the bacteria $\mathrm{A}^{\prime}$ and $\mathrm{B}^{\prime}$, as is seen by the increase in division rate and percentage of high divisions and the decrease in low divisions and deaths over those for these organisms when fed in pure culture. That this stimulation was very fleeting is evidenced by the fact that the actual duration of life of animals fed upon this mixture was no longer than for those fed with $\mathrm{A}$ alone. 
An entirely different picture is presented by the combination of $\mathrm{A}^{\prime}$ or $\mathrm{B}^{\prime}$ with $\mathrm{C}^{\prime}$. In the combination $\mathrm{A}^{\prime} \mathrm{C}^{\prime}$, a mixture was obtained which proved to be the most satisfactory of all the possible combinations of these three bacteria. The average division rate for the entire time, 131 days, was 1.793. During that time the percentage of high divisions was 40.3--a higher mark than was reached by the other combinations. The percentage of low divisions, 33.7, is somewhat higher than some of the others, but this is more than compensated for by the exceedingly low death rate of 3.3 per cent. We have here a very striking example of the stimulation of the metabolism of Paramecium when fed with a mixture of a bacterium in itself incapable of maintaining a high rate of metabolism in Paramecium with one which, when fed alone, failed utterly to support life. That this increase in the metabolic rate is of real significance is shown by computing the probable error of the constants of the two uncorrelated series, $\mathrm{C}^{\prime}$ and $\mathrm{A}^{\prime} \mathrm{C}^{\prime}$, according to the formula $\sqrt{\left(\mathrm{E}_{1}\right)^{2}+\left(\mathrm{E}_{2}\right)^{2}}$.

Here, $E_{1}$ and $E_{2}$ represent the probable errors in the mean division rates of $\mathrm{C}^{\prime}$ and $\mathrm{A}^{\prime} \mathrm{C}^{\prime}$, respectively, when computed according to Peter's formula for the probable error (Huntington, '18), namely:

$$
\mathrm{E}=\frac{0.08453}{\mathrm{n} \sqrt{\mathrm{n}-1}}\left(\mathrm{v}_{1}+\mathrm{v}_{2}+\mathrm{v}_{3}+\ldots \ldots \mathrm{v}_{\mathrm{n}}\right)
$$

It is well known in biometry that if the probable error of the difference in the constants of two uncorrelated series is contained more than three times in the numerical value representing the difference in the means under the two experimental conditions, the results are of statistical significance. For such a quotient I have used the expression 'significance factor,' a term suggested by Doctor Obreshkove. It is evident that the greater this factor, the greater the value of the numerical data. In the case of $\mathrm{C}^{\prime}$ and $\mathrm{A}^{\prime} \mathrm{C}^{\prime}$, the difference in the mean division rates is 0.760 . The probable error of the mean rate of division for $\mathrm{C}^{\prime}$ is 0.0462 ; that for $\mathrm{A}^{\prime} \mathrm{C}^{\prime}$ is 0.0624 . Applying the formula, $\sqrt{\left(\mathrm{E}_{1}\right)^{2}+\left(\mathrm{E}_{2}\right)^{2}}$, the probable error of the difference in the constants of these two series, $\mathrm{C}^{\prime}$ and $\mathrm{A}^{\prime} \mathrm{C}^{\prime}$, is 0.775 . 'This is contained in the difference 
in the mean division rates (0.0760) 9.832 times. This whole reaction may be expressed as follows:

$$
\frac{1.793-1.033}{\sqrt{(0.0462)^{2}+(0.0624)^{2}}}=\frac{0.760}{0.0775}=9.832 \text {. }
$$

Therefore, the increase in metabolism, as indicated by the increased division rate for $\mathrm{A}^{\prime} \mathrm{C}^{\prime}$, is significant, and demonstrates that the addition of $\mathrm{A}^{\prime}$ to $\mathrm{C}^{\prime}$ produced a food for Paramecium of much greater value than $\mathrm{C}^{\prime}$ alone. The data from which the significance factors were derived are given in table 2 .

TABLE 2

Mean division rates with their probable errors, differences in mean division rates with probable errors of the differences, and significance factors for the data summarized in table 1

\begin{tabular}{|c|c|c|c|c|c|c|}
\hline FOOD & $\begin{array}{l}\text { MEAN } \\
\text { DIVISTON } \\
\text { RATE }\end{array}$ & $\begin{array}{l}\text { PROBABLE } \\
\text { ERROR }\end{array}$ & \multicolumn{2}{|c|}{ DIFFERENCE IN MEAN DIVISION RATE } & $\begin{array}{c}\text { PROBABLE } \\
\text { ERROR OF } \\
\text { DIFFER- }\end{array}$ & $\begin{array}{l}\text { SIGNIFI- } \\
\text { CANCE } \\
\text { FACTOR }\end{array}$ \\
\hline $\mathrm{C}^{\prime}$ & 1.033 & 0.0462 & $\mathrm{C}^{\prime} \& \mathrm{~A}^{\prime} \mathrm{C}^{\prime}$ & 0.760 & 0.0775 & 9.832 \\
\hline$A^{\prime} C^{\prime}$ & 1.793 & 0.0624 & $\mathrm{C}^{\prime} \& \mathrm{~A}^{\prime} \mathrm{B}^{\prime} \mathrm{C}^{\prime}$ & 0.497 & 0.0863 & 5.758 \\
\hline$A^{\prime} B^{\prime} C^{\prime}$ & 1.530 & 0.0732 & $\mathbf{C}^{\prime} \&$ & 0.411 & 0.110 & 3.736 \\
\hline $\mathbf{M}$ & 1.444 & 0.0997 & $\mathrm{~A}^{\prime} \mathrm{C}^{\prime} \& \mathrm{~A}^{\prime} \mathrm{B}^{\prime} \mathrm{C}^{\prime}$ & 0.263 & 0.0960 & 2.635 \\
\hline & & & $\mathrm{A}^{\prime} \mathrm{C}^{\prime} \& \quad \mathrm{M}$ & 0.349 & 0.121 & 2.88 \\
\hline & & & $\mathrm{A}^{\prime} \mathrm{B}^{\prime} \mathrm{C}^{\prime} \&$ & 0.086 & 0.122 & 0.704 \\
\hline
\end{tabular}

When $\mathrm{B}^{\prime}$ was combined with $\mathrm{C}^{\prime}$, a food was obtained, which, although far more satisfactory than $\mathrm{B}^{\prime}$ in pure culture, nevertheless failed to maintain a high rate of metabolism in Paramecium. This mixture was, therefore, discontinued after twenty-seven days' trial.

When to $\mathrm{C}^{\prime}$ were added both $\mathrm{A}^{\prime}$ and $\mathrm{B}^{\prime}$, a fairly satisfactory food was obtained, the average daily division rate being 1.530 for 127 days. The significance factor for $\mathrm{A}^{\prime} \mathrm{B}^{\prime} \mathrm{C}^{\prime}$ and $\mathrm{C}^{\prime}$ is 5.758 , showing the mixture to be quite superior to $\mathrm{C}^{\prime}$ alone. If we compare $\mathrm{A}^{\prime} \mathrm{C}^{\prime}$ and $\mathrm{A}^{\prime} \mathrm{B}^{\prime} \mathrm{C}^{\prime}$, we find a significance factor of 2.635 , which indicates no real difference in the relative food values of these two mixtures. Other data than division rate suggest that $\mathrm{A}^{\prime} \mathrm{C}^{\prime}$ may be slightly better than $\mathrm{A}^{\prime} \mathrm{B}^{\prime} \mathrm{C}^{\prime}$.

The mixture $\mathrm{M}$ appears to be less favorable than either $\mathrm{A}^{\prime} \mathrm{C}^{\prime}$ or $\mathrm{A}^{\prime} \mathrm{B}^{\prime} \mathrm{C}^{\prime}$, for the metabolic rate of Paramecium is lower than 
with either of the artificial mixtures, the daily rate for $\mathrm{M}$ averaging 1.444 for ninety-two days. But the differences between these mixtures are not sufficiently great to have any meaning, since we find the significance factors as follows: $\mathrm{M}$ and $\mathrm{A}^{\prime} \mathrm{C}^{\prime}, 2.880$; $\mathrm{M}$ and $\mathrm{A}^{\prime} \mathrm{B}^{\prime} \mathrm{C}^{\prime}, 0.704$. If we consider the control mixture $\mathrm{M}$ only for the first three periods, during which time it supported a higher metabolic rate in Paramecium, we find no ground for changing the conclusions already given. For these three periods $\mathrm{M}$ was superior to $\mathrm{C}^{\prime}$, while $\mathrm{M}, \mathrm{A}^{\prime} \mathrm{C}^{\prime}$, and $\mathrm{A}^{\prime} \mathrm{B}^{\prime} \mathrm{C}^{\prime} \operatorname{did}$ not show suff cient difference to give a significance factor equal to 3 in any case.

These figures thus make it clear that the mixtures of bacteria maintain a higher rate of metabolism in Paramecium than do the pure cultures of the bacteria comprising the mixtures. There appear to be differences in the mixtures, for the daily rate of division would indicate that $\mathrm{A}^{\prime} \mathrm{C}^{\prime}$ was best, then comes $\mathrm{A}^{\prime} \mathrm{B}^{\prime} \mathrm{C}^{\prime}$, and $\mathrm{M}$ last. But the biometrical tests applied showed the differences to be too small to warrant any belief in the marked superiority of one mixture over the others.

The time during which the various cultures of the bacteria $\mathrm{A}^{\prime}, \mathrm{B}^{\prime}$, and $\mathrm{C}^{\prime}$ were used for feeding was divided into five periods, because of the necessity for occasional washing of the animals and because, for the purposes of this investigation, it seemed wise to avoid experimental work during endomixis. The phenomena of endomixis are accompanied by a marked slowing of the division rate, and it was thought that the effect of the different kinds of food would not be so evident at these times. The occurrence of fragmentation of the macronucleus as shown in stained specimens was taken as evidence of endomixis, and this was determined as taking place in this strain of Paramecium every thirty to thirty-five days.

It was found to be well-nigh impossible to revive the animals after the first endomixis period, which began September 28, 1920. Vigorous, rapidly dividing animals were not secured until October 10th. I have been at a loss to account for this condition of low vitality, save that it was in some way the result of environment. The animals passed through this endomixis in the control mixture 
$M$ and only a single animal survived. All the Paramecia used in the subsequent experiments were derived from this single animal. It is interesting to note that no such period of marked depression occurred later among the animals fed upon the artificial mixtures of bacteria, which seemed to be efficient in maintaining the normal rhythm emphasized by Woodruff and Erdmann ('14). The question immediately arises: Are we dealing in the case of the artificial mixtures with a type of food, capable in itself of preventing the periods of marked depression noted by Calkins ('02 a), and avoided by Woodruff by the use of a 'varied culture medium'? This could be determined only by attempting to feed Paramecium such a mixture many months, and is a problem in itself.

Since, as is indicated in table 1 , the bacteria $A^{\prime}, B^{\prime}$ and the mixture $\mathrm{A}^{\prime} \mathrm{B}^{\prime}$ did not prove to be satisfactory as food, they have not been included in the tables and graphs which follow.

TABLE 3a

Summary of results of feeding Paramecium aurelia in 0.1 per cent standard timothy hay infusion with the bacteria $C^{\prime}, A^{\prime} C^{\prime}, B^{\prime} C^{\prime}, A^{\prime} B^{\prime} C^{\prime}$, and $M$, for period $I$, from August 28, 1920, to September 28, 1920

\begin{tabular}{c|c|c|c|c|c}
\hline \multirow{2}{*}{ FOOD } & $\begin{array}{c}\text { AVERAGE } \\
\text { NUMBER DAIY } \\
\text { DIVISIONS }\end{array}$ & $\begin{array}{c}\text { PER CENT HIGH } \\
\text { DIVISIONS }\end{array}$ & $\begin{array}{c}\text { PER CENT LOW } \\
\text { DIVISIONG }\end{array}$ & $\begin{array}{c}\text { PER CENT OF } \\
\text { DEATH }\end{array}$ & $\begin{array}{c}\text { NUMBER OF } \\
\text { DAYS }\end{array}$ \\
\cline { 2 - 2 } $\mathrm{C}^{\prime}$ & $\mathbf{0 . 9 6 7}$ & 20.2 & 43.5 & 3.3 & 31 \\
$\mathrm{~A}^{\prime} \mathrm{C}^{\prime}$ & 1.712 & 61.1 & 13.3 & 3.3 & 31 \\
$\mathrm{~B}^{\prime} \mathrm{C}^{\prime}$ & 1.305 & 37.2 & 26.4 & 11.8 & 27 \\
$\mathrm{~A}^{\prime} \mathrm{B}^{\prime} \mathrm{C}^{\prime}$ & 1.710 & 52.9 & 28.8 & 1 & 28 \\
$\mathrm{M}$ & 2.047 & 81.1 & 6.6 & 0.4 & 31 \\
\hline
\end{tabular}

TABLE $3 \mathrm{~b}$

Summary of results of feeding Paramecium with bacteria $C^{\prime}, A^{\prime} C^{\prime}, A^{\prime} B^{\prime} C^{\prime}$, and $M$, in 0.1 per cent standard hay infusion for period $I I$, from October 20, 1920, to November 24, 1920

\begin{tabular}{c|c|c|c|c|c}
\hline \multirow{2}{*}{ FOOD } & $\begin{array}{c}\text { AVERAGE } \\
\text { NUMBER DAILY } \\
\text { DIVISIONS }\end{array}$ & $\begin{array}{c}\text { PER CENT HIGH } \\
\text { DIVISIONS }\end{array}$ & $\begin{array}{c}\text { PER GENT LOW } \\
\text { DIVISIONS }\end{array}$ & $\begin{array}{c}\text { PER CENT OF } \\
\text { DEATH }\end{array}$ & $\begin{array}{c}\text { NUMBER OF } \\
\text { DAYS }\end{array}$ \\
\cline { 1 - 2 } $\mathrm{C}^{\prime}$ & 1.006 & 20.3 & 32.5 & 5.6 & 35 \\
\cline { 1 - 2 } $\mathrm{A}^{\prime} \mathrm{C}^{\prime}$ & 1.65 & 46.7 & 29.4 & 2.2 & 35 \\
$\mathrm{~A}^{\prime} \mathrm{B}^{\prime} \mathrm{C}^{\prime}$ & 1.433 & 35 & 28.5 & 10.4 & 34 \\
$\mathrm{M}$ & 1.214 & 27.3 & 28.6 & 12.3 & 32 \\
\hline
\end{tabular}


TABLE 3c

Summary of results for period III, from December 5, 1920, to December 28, 1920. Food and media as in table $3 b$

\begin{tabular}{|c|c|c|c|c|c|}
\hline FOOD & $\begin{array}{l}\text { AVERAGF } \\
\text { NUMBER DAILY } \\
\text { DIVISIONG }\end{array}$ & $\begin{array}{l}\text { PER CENT HIGH } \\
\text { DIVISIONS }\end{array}$ & $\begin{array}{l}\text { PER CENT LOW } \\
\text { DIVIGIONS }\end{array}$ & $\begin{array}{l}\text { PER CENT OF } \\
\text { DEATH }\end{array}$ & $\begin{array}{c}\text { NUMBER OF } \\
\text { DAYB }\end{array}$ \\
\hline $\mathrm{C}^{\prime}$ & 1.13 & 21.6 & 33.6 & 4.8 & 21 \\
\hline $\mathrm{A}^{\prime} \mathrm{C}^{\prime}$ & 2.108 & 59.8 & 16.3 & 7.7 & 21 \\
\hline $\mathrm{A}^{\prime} \mathrm{B}^{\prime} \mathrm{C}^{\prime}$ & 1.883 & 50.8 & 18.2 & 11.3 & 21 \\
\hline M & 1.098 & 23.4 & 36.3 & 7.3 & 20 \\
\hline
\end{tabular}

TABLE 3d

Summary of results for period IV, from January 12, 1921 to February 5, 1921. Food and medium as above

\begin{tabular}{r|c|c|c|c|c}
\hline \multicolumn{1}{c|}{ FoOD } & $\begin{array}{c}\text { AVERAGE } \\
\text { NUMBER DAILY } \\
\text { DIVISIONS }\end{array}$ & $\begin{array}{c}\text { PER CENT HIGH } \\
\text { DIVISIONS }\end{array}$ & $\begin{array}{c}\text { PER CENT LOW } \\
\text { DIVISIONB }\end{array}$ & $\begin{array}{c}\text { PER CENT OF } \\
\text { DEATH }\end{array}$ & $\begin{array}{c}\text { NUMAER OF } \\
\text { DAYB }\end{array}$ \\
\hline $\mathrm{C}^{\prime}$ & 0.906 & 15.5 & 34.8 & 7 & 20 \\
$\mathrm{~A}^{\prime} \mathrm{C}^{\prime}$ & 1.303 & 38 & 29.3 & 3.8 & 21 \\
$\mathrm{~A}^{\prime} \mathrm{B}^{\prime} \mathrm{C}^{\prime}$ & 1.168 & 28.3 & 28.3 & 4.9 & 21 \\
$\mathrm{M}$ & 1.058 & 9.4 & 10.8 & 37.7 & 61 \\
\hline
\end{tabular}

TABLE 3e

Summary of results for period $V$, from February 13, 1921, to March 7, 1921. Food and medium as above

\begin{tabular}{r|c|c|c|c|c}
\hline Food & $\begin{array}{c}\text { AVERAGE } \\
\text { NuMBER DAILY } \\
\text { DIVISIONS }\end{array}$ & $\begin{array}{c}\text { PER CENT HIGH } \\
\text { DIVISIONS }\end{array}$ & $\begin{array}{c}\text { PER CENT LOW } \\
\text { DIVISIONS }\end{array}$ & $\begin{array}{c}\text { PER CENT OF } \\
\text { DEATH }\end{array}$ & $\begin{array}{c}\text { NUMBER OF } \\
\text { DAYs }\end{array}$ \\
\hline $\mathrm{C}^{\prime}$ & 1.254 & 32.2 & 37.4 & 4.3 & 23 \\
$\mathrm{~A}^{\prime} \mathrm{C}^{\prime}$ & 2.084 & 69.1 & 15.2 & 1 & 23 \\
$\mathrm{~A}^{\prime} \mathrm{B}^{\prime} \mathrm{C}^{\prime}$ & 1.384 & 40.2 & 7.1 & 10.2 & 23 \\
$\mathrm{M}$ & 0.727 & 23.1 & 15.3 & 15.4 & $3^{2}$ \\
\hline
\end{tabular}

1 Died and restarted after a week's interval, then died again.

2 Started three days before end of period. Showed low vitality.

Tables 3, a to e, demonstrate that the chance mixture M showed a steady decline in all factors considered. This decline, however, was not evident during the daily course of the work, for, as the graphs show, such fluctuations as occurred would naturally be attributed to normal rhythms, and were not noticeably different from those occurring in the artificial mixtures. It was only when all evidence was collected and the final averages made that 
it could be seen that there was in reality a steady decline in the power of the chance mixture $M$ to maintain a normal rate of metabolism in Paramecium, and that the seemingly abrupt failure of this mixture was, after all, only apparent.

The streptothrix $\mathrm{C}^{\prime}$, the only organism of those tested which proved to be a satisfactory food when used in pure culture, is a filamentous organism, the individual filaments of which are too large for Paramecium to ingest. The animal was, therefore, forced to subsist upon the fruiting bodies or upon very young filaments. The questions might be raised: Was not the low metabolic rate of the animals fed with this organism due to an insufficient amount of food? Was the supply of fruiting bodies adequate? It is probable that the food was quite adequate in amount and the increases in activity noted for these animals were not due to any increase in the reproductive power of the streptothrix. It is far more likely, since they occurred synchronously with similar increases in other cultures, that they were associated with rhythms and had no direct relation to food.

The mean division rate for $\mathrm{C}^{\prime}$ for the entire series of observations was 1.033. An inspection of table 3 , shows that the division rate fell below this mean three times; at the beginning of the experiments and during the second and fourth periods. During the other periods it was slightly in excess of the mean rate. On the whole, it showed less variation from the mean than the other two artificial mixtures. The fourth period, during which the rate dropped below the mean, was marked by a fall in metabolic rate in all cultures. It is possible that the greater range in temperature combined with an unsatisfactory condition of $\mathrm{M}$ was sufficient to cause the death of the animals in this mixture.

When $\mathrm{A}^{\prime} \mathrm{C}^{\prime}$ is compared with $\mathrm{C}^{\prime}$, it is evident that the addition of $\mathrm{A}^{\prime}$ to $\mathrm{C}^{\prime}$ caused a marked acceleration or stimulation of the metabolic rate of Paramecium. The division rate exceded that of $\mathrm{C}^{\prime}$ during all the periods. The percentages of high divisions, low divisions, and deaths show an increased metabolism. There was more fluctuation in the death rate for $\mathrm{A}^{\prime} \mathrm{C}^{\prime}$, and it was greater than for $\mathrm{C}^{\prime}$ during the third period. It was found in computing 
the percentages for the three-day intervals that an increased death rate sometimes accompanied an increased metabolism. This suggests that an accelerated rate of metabolism may be paralleled by an excessive mortality, as if the unusual expenditure of energy was destructive to weak individuals. With the exception of these occasional increases, the death rate of $\mathrm{A}^{\prime} \mathrm{C}^{\prime}$ remained less than that for $\mathrm{C}^{\prime}$. The significance factor for the difference between $\mathrm{C}^{\prime}$ and $\mathrm{A}^{\prime} \mathrm{C}^{\prime}, 9.832$, indicates a marked acceleration of metabolism in animals fed with $\mathrm{A}^{\prime} \mathrm{C}^{\prime}$.

The analysis of the conditions obtaining in the feeding of the above mixtures is aided by a series of graphs of the division rates averaged for three-day intervals during the five periods of observation. An inspection of these graphs shows the superiority of the $\mathrm{A}^{\prime} \mathrm{C}^{\prime}$ mixture. It is true that for the first ten intervals, the average division rate, 1.712 , was less than that for $M$, which was in excess of 2 (table 3 a). A fission rate greater than 2 is unusual for Paramecium aurelia, yet the rate for $\mathrm{A}^{\prime} \mathrm{C}^{\prime}$ exceeded 2, twelve intervals out of a total of forty-four. The rate for the mixture $\mathrm{A}^{\prime} \mathrm{B}^{\prime} \mathrm{C}^{\prime}$, used for a total of forty-two intervals, exceeded 2 nine times, thus approximating $\mathrm{A}^{\prime} \mathrm{C}^{\prime}$. The division rate of the control, $\mathrm{C}^{\prime}$, did not exceed 2 in any of the averages for threeday intervals. Although the daily rate rose above this figure or equaled it 174 times between August and March, these high rates did not occur with suff.cient frequency to bring any single average for a three-day interval up to 2 .

Certain minor fluctuations in the rhythms are to be seen on an inspection of the graphs. These fluctuations are independent of those for the three-day intervals and of the occurrence of endomixis. They are evidence of an alternating elevation and depression of the metabolic rate which seems to be independent of food. They occur in all cultures and are fairly synchronous irrespective of the type of food used. The temperature of the laboratory was fairly constant; that for the liquid in which the animals were living was necessarily more constant than the air of the room, and this even temperature obtained throughout the course of the work save for a part of the winter when there was some variation. Since these minor fluctuations occurred during 
the time of even laboratory temperature as well as when it was more variable, it would seem that they cannot be entirely due to this factor. In the case of a satisfactory food like $\mathrm{A}^{\prime} \mathrm{C}^{\prime}$, the degree of fluctuation tends to be greater than with a food like $\mathrm{C}^{\prime}$, which is incapable of sustaining a high metabolic level in Paramecium. Aside from this fact, no definite correlation seems to exist between the occurrence of these fluctuations and the type of food used. They appear to be due to intrinsic factors affecting the metabolism irrespective of food or to slight variations in the environment not under control.

It is of interest to note that the chance mixture $M$, which throughout the first period appeared to be the most satisfactory kind of food used, showed the least degree of fluctuation of any of the cultures under observation during this period. That this mixture was comparable at this time to any laboratory infusion in which Paramecia thrive, there can be no reasonable doubt. That it did not continue to furnish conditions favorable to the continued life of Paramecium has been demonstrated. The question arises as to whether the high rate of metabolism of the animals in $M$ during this period was due to a preponderance of favorable types of bacteria which prevented the increase of unfavorable types. Since it is well known that bacteria vary in their resistance to drying, is it not possible that some of the more resistant forms are unsuitable food for Paramecium?

The foregoing observations may be summarized as follows: The data dealing with the behavior of Paramecium when fed in a standard 0.1 per cent timothy hay infusion upon a diet consisting of either a pure culture of $\mathrm{C}^{\prime}$, or its mixtures $\mathrm{A}^{\prime} \mathrm{C}^{\prime}$ and $\mathrm{A}^{\prime} \mathrm{B}^{\prime} \mathrm{C}^{\prime}$, and of the chance mixture $\mathrm{M}$, demonstrate that it is possible for this animal to live upon a single article of diet, although the metabolism under such conditions is not so high as when a mixed diet is used. The chance mixture $M$ was very much more satisfactory during the first period than either of the artificial mixtures, but such a chance mixture is not easily kept constant, and under the conditions of these experiments failed to maintain a continued normal rate of metabolism in the animals fed upon it. Of the artificial mixtures, $\mathrm{A}^{\prime} \mathrm{C}^{\prime}$ proved to be the most satisfactory and 


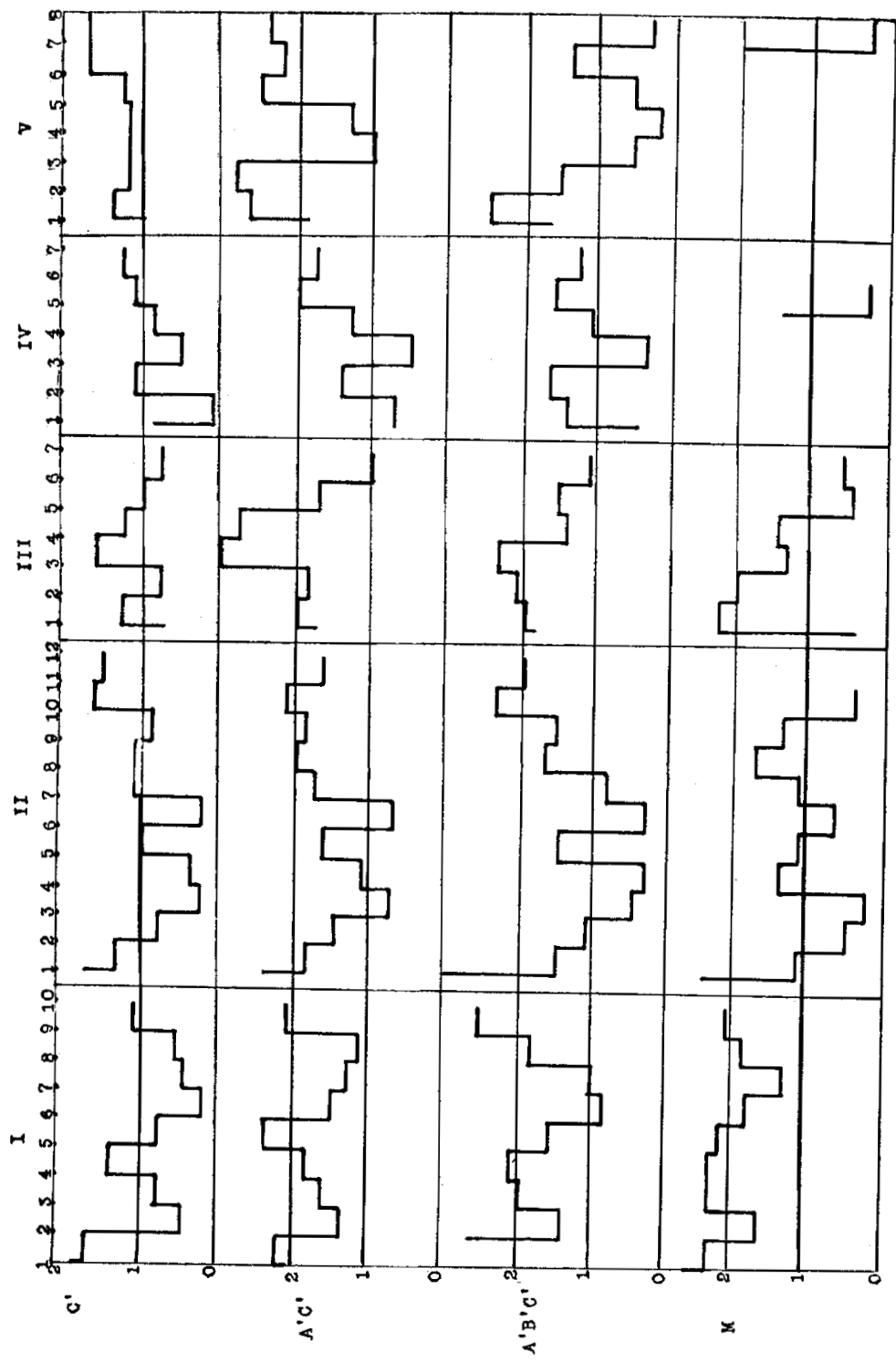

荧计

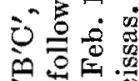

《初兽

ऐo is

$4 \frac{0}{0}$

$0 \div$

赵

ث

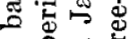

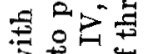

Fै

율 悹

要

范。

目 10

$\exists \dot{z}:$

경

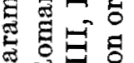

iñ

o. 就

능 穴递

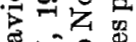

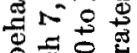

ใน

.

\&

क्ष

震必范

ర大

$-3_{30} \pm$

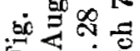

定要 
appears to be capable of maintaining a normal rate of metabolism over an extended period.

2. Change of food of Paramecium without change of medium. This section of the work consisted of two parts. First, Paramecia which had been fed for a long time upon the bacteria $\mathrm{C}^{\prime}$, $\mathrm{A}^{\prime} \mathrm{C}^{\prime}, \mathrm{A}^{\prime} \mathrm{B}^{\prime} \mathrm{C}^{\prime}$, and $\mathrm{M}$ were shifted from one such food to another, as, for example, animals fed upon $\mathrm{C}^{\prime}$ were washed and then placed in the $\mathrm{A}^{\prime} \mathrm{C}^{\prime}$ mixture; the presumably unfavorable foods, $A^{\prime}$ and $B^{\prime}$, were added to $M$, and other such shifts made as described below. The second part of the work consisted in an entire change of food. Animals which had been fed upon one of these combinations were washed and placed in pure cultures of bacteria used in the earlier part of the work. Table 4 gives the data for the first type of food change, and in table 5 are the probable errors and significance factors computed from the data of table 4. The original cultures were used as controls, and the change of food is indicated by changing the order of the letters used, e.g., cultures containing animals changed from $\mathrm{C}^{\prime}$ to a combination of $\mathrm{A}^{\prime}$ with this bacterium are designated as $\mathrm{C}^{\prime} \mathrm{A}^{\prime}$, to distinguish them from $\mathrm{A}^{\prime} \mathrm{C}^{\prime}$, the control of such a mixture. The culture, $\mathrm{C}^{\prime}$, serves as a control for all the mixtures used.

It is evident from the data in table 4 that the change from $\mathrm{C}^{\prime}$ to $\mathrm{C}^{\prime} \mathrm{B}^{\prime}$ resulted in a serious decrease in the vitality of the animals, for they could be kept alive but nine days in this mixture.

Animals changed from $\mathrm{C}^{\prime}$ to $\mathrm{C}^{\prime} \mathrm{A}^{\prime}$ appeared to experience an increase in metabolism. This increase was too slight to be due to the change in food as is suggested by the significance factor, 1.985. The disturbing effect of the change in environment was not overcome in the time during which the animals were under observation. The division rate failed to reach that of $\mathrm{A}^{\prime} \mathrm{C}^{\prime}$, and it is evident that in the change from $\mathrm{C}^{\prime}$ to a food presumably more satisfactory, the mere fact of the change tended to counteract the effect of the more favorable food to such an extent that the animals failed to show a marked reaction to this type of variation in the environment. The significance factors for all the other changes save $\mathrm{MA}^{\prime} \mathrm{B}^{\prime}$ tend to show the same thing. In the case of $\mathrm{MA}^{\prime} \mathrm{B}^{\prime}$, however, the significance factor, 3.965, in- 
dicates that the addition of $A^{\prime}$ and $B^{\prime}$ to the chance mixture had a stimulating effect.

TABLE 4

Data for the growth of Paramecium aurelia in the foods $C^{\prime}, A^{\prime} C^{\prime}, A^{\prime} B^{\prime} C^{\prime}$, and $M$, with the following changes in food; $C^{\prime}$, to $C^{\prime} A^{\prime}, C^{\prime} B^{\prime}, C^{\prime} A^{\prime} B^{\prime} ; A^{\prime} C^{\prime}$, to $A^{\prime} C^{\prime} B^{\prime}$; $M$, to $M A^{\prime}, M B^{\prime}$, and $M A^{\prime} B^{\prime}$, during the time from December 5,1920 , to December 28, 1920

\begin{tabular}{c|c|c|c|c|c}
\hline FOOD & $\begin{array}{c}\text { AVERAGE } \\
\text { NUMHER DAILY } \\
\text { DIVISIONS }\end{array}$ & $\begin{array}{c}\text { PER CENT HIGB } \\
\text { DIVISIONS }\end{array}$ & $\begin{array}{c}\text { PER CENT LOW } \\
\text { DIVISIONS }\end{array}$ & $\begin{array}{c}\text { PER CENT OF } \\
\text { DEATH }\end{array}$ & $\begin{array}{c}\text { NUMBER OF } \\
\text { DAYS }\end{array}$ \\
\cline { 1 - 2 } $\mathrm{C}^{\prime}$ & $\mathbf{1 . 1 3}$ & 21.6 & 33.6 & 4.8 & 21 \\
$\mathrm{~A}^{\prime} \mathrm{C}^{\prime}$ & 2.108 & 59.8 & 16.3 & 7.7 & 21 \\
$\mathrm{~A}^{\prime} \mathrm{B}^{\prime} \mathrm{C}^{\prime}$ & 1.883 & 50.8 & 18.2 & 11.3 & 21 \\
$\mathrm{M}$ & $\mathbf{1 . 0 9 8}$ & 23.4 & 36.3 & 7.3 & 20 \\
& & & & & \\
$\mathrm{C}^{\prime} \mathrm{A}^{\prime}$ & 1.535 & 50.6 & 18 & 10 & 20 \\
$\mathrm{C}^{\prime} \mathrm{B}^{\prime}$ & 0.794 & 10.4 & 44.8 & 27.6 & 9 \\
$\mathrm{C}^{\prime} \mathrm{A}^{\prime} \mathrm{B}^{\prime}$ & 1.880 & 52.6 & 15.9 & 7.9 & 20 \\
$\mathrm{~A}^{\prime} \mathrm{C}^{\prime} \mathrm{B}^{\prime}$ & 1.936 & 57.1 & 14.3 & 7.2 & 18 \\
$\mathrm{MA}^{\prime}$ & 1.177 & 29 & 29 & 10.1 & 19 \\
$\mathrm{MB}^{\prime}$ & 1.233 & 30 & 30 & 7.5 & 20 \\
$\mathrm{MA}^{\prime} \mathrm{B}^{\prime}$ & 1.504 & 38.6 & 26.3 & 7 & 16 \\
\hline
\end{tabular}

TABLE 5

Mean division rates with their probable errors, differences in mean division rates with probable errors of the differences, and significance factors

for the data summarized

\begin{tabular}{|c|c|c|c|c|c|c|c|}
\hline \multirow{2}{*}{ Food } & \multirow{2}{*}{$\begin{array}{c}\begin{array}{c}\text { MEAN } \\
\text { DIVISION } \\
\text { RATE }\end{array} \\
1.13\end{array}$} & \multirow{2}{*}{$\begin{array}{c}\begin{array}{c}\text { PROBABLE } \\
\text { ERROR }\end{array} \\
0.0911\end{array}$} & \multicolumn{3}{|c|}{ DIFFERENCE IN MEAN DIVISION RATE } & \multirow{2}{*}{$\begin{array}{c}\text { PROBABLE } \\
\text { ERROR } \\
\text { OF DIFFER- } \\
\text { ENCE } \\
0.1072\end{array}$} & \multirow{2}{*}{$\begin{array}{r}\begin{array}{r}\text { SIGNIFI- } \\
\text { CANCE } \\
\text { FACTOR }\end{array} \\
9.140\end{array}$} \\
\hline & & & $\mathrm{C}^{\prime}$ and & $\mathrm{A}^{\prime} \mathrm{C}^{\prime}$ & 0.978 & & \\
\hline $\mathrm{A}^{\prime} \mathrm{C}^{\prime}$ & 2.108 & 0.0180 & $\mathrm{C}^{\prime}$ " & $A^{\prime} B^{\prime} C^{\prime}$ & 0.755 & 0.1453 & 5.193 \\
\hline$A^{\prime} B^{\prime} C^{\prime}$ & 1.883 & 0.1132 & $\mathrm{C}^{\prime}$ “ & $\mathrm{C}^{\prime} \mathrm{A}^{\prime}$ & 0.405 & 0.2045 & 1.985 \\
\hline M & 1.098 & 0.1735 & $C^{\prime}$ "6 & $\mathrm{C}^{\prime} \mathrm{A}^{\prime} \mathrm{B}^{\prime}$ & 0.653 & 0.2417 & 2.709 \\
\hline $\mathrm{C}^{\prime} \mathrm{A}^{\prime}$ & 1.535 & 0.1831 & $A^{\prime} C^{\prime} "$ & $\mathrm{~A}^{\prime} \mathrm{C}^{\prime} \mathrm{B}^{\prime}$ & 0.172 & 0.1667 & 1.036 \\
\hline $\mathrm{C}^{\prime} \mathrm{A}^{\prime} \mathrm{B}^{\prime}$ & 1.880 & 0.2239 & $\mathrm{M}$ “ & $\mathrm{MA}^{\prime}$ & 0.230 & 0.2771 & 0.830 \\
\hline$A^{\prime} C^{\prime} B^{\prime}$ & 1.936 & 0.1570 & $M \approx$ & $\mathrm{MB}^{\prime}$ & 0.427 & 0.2431 & 1.757 \\
\hline $\mathrm{MA}^{\prime}$ & 1.177 & 0.2162 & $M "$ & $\mathrm{MA}^{\prime} \mathrm{B}^{\prime}$ & 1.150 & 0.2902 & 3.965 \\
\hline $\mathrm{MB}^{\prime}$ & 1.233 & 0.1705 & & & & & \\
\hline $\mathrm{MA}^{\prime} \mathrm{B}^{\prime}$ & 1.504 & 0.2327 & & & & & \\
\hline
\end{tabular}

This experiment shows that changes of the sort attempted are usually accompanied by so much disturbance that no marked 
increase in metabolism results and the animals fail to reach the metabolic level of their respective controls. Although these results indicate that it is desirable to maintain a constancy of satisfactory food, one would not be justified in maintaining that this is always the case. Further investigation of such phenomena as have been described is needed.

After testing the effect of such changes in food, it was decided to make a more radical change and determine how this particular line of Paramecium would react toward certain of the bacteria which had previously been found to be unsatisfactory. The bacterial cultures $\mathrm{J}, \mathrm{K}$, and $\mathrm{L}$ were used separately and in combination with one another. They proved to be as unsatisfactory as when previously used, the change from a favorable food like $\mathrm{A}^{\prime} \mathrm{C}^{\prime}$ being immediately followed by a marked depression of the division rate and a speedy death of the animals.

Under the conditions of the above experiments, change in food of Paramecium had one of two effects dependent on the nature of the food. When the change was from one satisfactory type to another, the evidence was in favor of a constancy of food under the conditions obtaining in this experiment. If, however, the change was from a markedly satisfactory to a decidedly unsatisfactory type of bacteria, a sudden lowering of the metabolic rate occurred, resulting in the speedy death of the animals.

3. Changing the medium without varying the food. Since so much emphasis has been laid by workers with Paramecium upon the nature of the medium in which the animals were cultivated, it was considered desirable to try the effect of a change in medium without varying the food, in order to throw more light, if possible, on the relation of this animal to the medium when it was furnished with a food which long trial had shown to be satisfactory. The media used were made according to the same formula as the standard hay infusion, and used in the same way for growing the bacteria used for feeding. The first infusion tested was made from dry, uncured swamp hay, and the results of using this are summarized in table 6 . 
It will be seen from a study of this table that any variation in the division rate of the animals in the new medium from that of those in the standard hay infusion was so slight as to be of no importance. The fact that $M$ failed during the last period of this experiment when used in the new medium is not necessarily

TABLE 6a

Showing the results of feeding Paramecium with the bacteria $C^{\prime}, A^{\prime} C^{\prime}, A^{\prime} B^{\prime} C^{\prime}$, and $M$, in the 0.1 per cent standard timothy hay infusion and in 0.1 per cent uncured swamp-hay infusion, during the time from November 6, 1920, to November 26, 1920. Data for the swamp-hay medium in the second row in each case

\begin{tabular}{|c|c|c|c|c|c|}
\hline FOOD & $\begin{array}{c}\text { AVERAGE } \\
\text { NUMBER DAILY } \\
\text { DIVISIONS }\end{array}$ & $\begin{array}{l}\text { PER CENT HIGH } \\
\text { DIVIBIONS }\end{array}$ & $\begin{array}{l}\text { PER CENT LOW } \\
\text { DIYISIONB }\end{array}$ & $\begin{array}{c}\text { PER CENT OF } \\
\text { DEATH }\end{array}$ & $\begin{array}{c}\text { NOMBER OF } \\
\text { DAYS }\end{array}$ \\
\hline \multirow{2}{*}{$\mathrm{C}^{\prime}$} & 1.184 & 18.4 & 32.5 & 6.6 & 18 \\
\hline & 1.144 & 18.8 & 37.1 & 4 & 18 \\
\hline \multirow{2}{*}{$A^{\prime} C^{\prime}$} & 1.677 & 42.3 & 30.6 & 2.4 & 18 \\
\hline & 1.536 & 40.9 & 31.3 & 4.5 & 18 \\
\hline \multirow{2}{*}{$A^{\prime} B^{\prime} C^{\prime}$} & 1.506 & 38.8 & 29.1 & 2.4 & 18 \\
\hline & 1.546 & 41.5 & 36.3 & 2.3 & 18 \\
\hline \multirow{2}{*}{ M } & 1.315 & 21.1 & 37.4 & 14.3 & 16 \\
\hline & 1.386 & 11.8 & 32.7 & 13.7 & 16 \\
\hline
\end{tabular}

TABLE $6 \mathrm{~b}$

Showing results of feeding Paramecium with the same bacteria in the same media as in $6 a$, during the time from December 5, 1920, to December 28,1920

\begin{tabular}{|c|c|c|c|c|c|}
\hline FOOD & $\begin{array}{c}\text { AVERAGE } \\
\text { NUMBER DAILY } \\
\text { DIVISIONS }\end{array}$ & $\begin{array}{l}\text { PER CENT HIGH } \\
\text { DIVISIONS }\end{array}$ & $\begin{array}{l}\text { PER CENT LOW } \\
\text { DIVISIONS }\end{array}$ & $\begin{array}{c}\text { PERCENT OF } \\
\text { DEATH }\end{array}$ & $\begin{array}{c}\text { NUMBER oF } \\
\text { DAYS }\end{array}$ \\
\hline \multirow{2}{*}{$\mathrm{C}^{\prime}$} & 1.138 & 28.6 & 33.6 & 4.8 & 21 \\
\hline & 1.186 & 26.7 & 20.4 & 7.9 & 21 \\
\hline \multirow{2}{*}{$\mathrm{A}^{\prime} \mathrm{C}^{\prime}$} & 1.877 & 59.8 & 16.3 & 7.7 & 21 \\
\hline & 1.861 & 58 & 21.3 & 3.6 & 21 \\
\hline \multirow{2}{*}{$\mathrm{A}^{\prime} \mathrm{B}^{\prime} \mathrm{C}^{\prime}$} & 1.868 & 50.8 & 18.2 & 11.3 & 21 \\
\hline & 1.771 & 46.5 & 19.4 & 10 & 16 \\
\hline \multirow{2}{*}{ M } & 1.386 & 23.4 & 36.3 & 7.3 & 20 \\
\hline & 1.45 & 32.1 & 8.9 & 26.8 & 7 \\
\hline
\end{tabular}


TABLE 6c

Summarizing the data contained in tables $6 a$, and $6 b$, for the time from November 6 , 1920, to December 28,1920

\begin{tabular}{|c|c|c|c|c|c|}
\hline FOOD & $\begin{array}{c}\text { AVERAGE } \\
\text { NUMBER DAILY } \\
\text { DIVISIONG }\end{array}$ & $\begin{array}{l}\text { PER CENT HIGH } \\
\text { DIVISIONS }\end{array}$ & $\begin{array}{l}\text { PER CENT LOW } \\
\text { DIVIEIONG }\end{array}$ & $\begin{array}{l}\text { PER CFNT OF } \\
\text { DEATHE }\end{array}$ & $\begin{array}{c}\text { NUMBER OF } \\
\text { DAYA }\end{array}$ \\
\hline \multirow{2}{*}{$\mathrm{C}^{\prime}$} & 1.162 & 19.8 & 32.9 & 5.9 & 39 \\
\hline & 1.113 & 22.9 & 28.4 & 6.2 & 39 \\
\hline \multirow{2}{*}{$\mathrm{A}^{\prime} \mathrm{C}^{\prime}$} & 1.756 & 49.4 & 24.7 & 4.6 & 39 \\
\hline & 1.705 & 49.9 & 26 & 4.1 & 39 \\
\hline \multirow{2}{*}{$\mathrm{A}^{\prime} \mathrm{B}^{\prime} \mathrm{C}^{\prime}$} & 1.695 & 45.5 & 23.2 & 7.3 & 39 \\
\hline & 1.652 & 43.9 & 28 & 6.1 & 34 \\
\hline \multirow{2}{*}{ M } & 1.348 & 22.1 & 36.9 & 11.1 & 36 \\
\hline & 1.478 & 21.9 & 20.8 & 20.2 & 23 \\
\hline
\end{tabular}

due to a depressing effect of the medium. It is just as probable that the change in environment in a culture which was becoming unsatisfactory was enough to cause the death of the animals. Had the food in the mixture M been as satisfactory as was the case when this was first used, it is not likely that the death rate in the new medium would have been greater.

The second infusion tested was made of entirely different material, the dry, uncured, succulent moneywort, Lysimachia nummularia L. It presumably had a different chemical composition than either of the other infusions used. As in the case of the uncured swamp hay, it was tested in connection with controls in the standard 0.1 per cent hay infusion. The effect of using this infusion is shown in table 7 .

The first impression one gains from a study of this table is that the change from hay infusion to moneywort produced a marked increase in metabolism of the animals thus treated. The significance factors for these changes do not indicate that this was the case save for the mixture $\mathrm{A}^{\prime} \mathrm{B}^{\prime} \mathrm{C}^{\prime}$. However, since there was a stimulating effect of the medium in this one case, we are justified in concluding that this particular change in medium tended to be stimulating rather than depressing or without effect. 
During the second period of observation the animals passed through an endomixis. This was accompanied by a lowering of the division rate, as was to be expected, and after recovery the rate for the animals in the new medium remained slightly

\section{TABLE 7a}

Showing results of feeding Paramecium with the bacteria $C^{\prime}, A^{\prime} C^{\prime}, A^{\prime} B^{\prime} C^{\prime}$, and $M$ in the 0.1 per cent standard timothy hay infusion, and in 0.1 per cent dry uncured moneywort infusion, during the time from January 12, 1921, to February 5, 1921. Data for the moneywort infusion in the second line in each case

\begin{tabular}{|c|c|c|c|c|c|c|}
\hline FOOD & $\begin{array}{c}\text { AVERAGE } \\
\text { NUMBER } \\
\text { DAISY } \\
\text { DIVISIONS }\end{array}$ & $\begin{array}{l}\text { PER CENT } \\
\text { HIGH } \\
\text { DIVISIONg }\end{array}$ & $\begin{array}{l}\text { PER CENT } \\
\text { LOW } \\
\text { DIVISIONS }\end{array}$ & $\begin{array}{l}\text { PER CENT } \\
\text { OF DEATR }\end{array}$ & $\begin{array}{l}\text { NUMBER } \\
\text { OF DAYB }\end{array}$ & $\begin{array}{l}\text { SIGNIPI- } \\
\text { CANCE } \\
\text { FACTOR }\end{array}$ \\
\hline $\mathrm{C}^{\prime}$ & $\begin{array}{l}0.906 \\
1.485\end{array}$ & $\begin{array}{l}15.5 \\
52\end{array}$ & $\begin{array}{l}34.8 \\
16.7\end{array}$ & $\begin{array}{l}7 \\
2.5\end{array}$ & $\begin{array}{l}20 \\
20\end{array}$ & 2.453 \\
\hline$A^{\prime} C^{\prime}$ & $\begin{array}{l}1.303 \\
2.023\end{array}$ & $\begin{array}{l}38 \\
54.5\end{array}$ & $\begin{array}{l}29.3 \\
15\end{array}$ & $\begin{array}{l}3.8 \\
9\end{array}$ & $\begin{array}{l}20 \\
20\end{array}$ & 2.647 \\
\hline$A^{\prime} B^{\prime} C^{\prime}$ & $\begin{array}{l}1.168 \\
2.184\end{array}$ & $\begin{array}{l}28.3 \\
58.5\end{array}$ & $\begin{array}{l}28.8 \\
23.5\end{array}$ & $\begin{array}{l}4.9 \\
5.5\end{array}$ & $\begin{array}{l}21 \\
21\end{array}$ & 4.080 \\
\hline M & $\begin{array}{l}0.764 \\
0.643\end{array}$ & $\begin{array}{l}9.4 \\
3.5\end{array}$ & $\begin{array}{l}20.8 \\
24.6\end{array}$ & $\begin{array}{l}37.7 \\
42.1\end{array}$ & $\begin{array}{l}6 \\
6\end{array}$ & \\
\hline
\end{tabular}

TABLE 7b

Showing the results of feeding Paramecium with the same bacteria in the same media, as in table 7a, during the time from February 13, 1921, to March $\%, 1921$

\begin{tabular}{|c|c|c|c|c|c|c|}
\hline FOOD & $\begin{array}{c}\text { AVERAGE } \\
\text { NUMBER } \\
\text { DAILY } \\
\text { DIVISIONB }\end{array}$ & $\begin{array}{l}\text { PER CENT } \\
\text { HIGH } \\
\text { DIVISIONS }\end{array}$ & $\begin{array}{l}\text { PER CENT } \\
\text { LOW } \\
\text { DIVISIONS }\end{array}$ & $\begin{array}{l}\text { PER CENT } \\
\text { OF DEATH }\end{array}$ & $\begin{array}{l}\text { NUMBFR } \\
\text { OF DAYS }\end{array}$ & $\begin{array}{l}\text { BIGNIFI- } \\
\text { CANCE } \\
\text { FACTOR }\end{array}$ \\
\hline \multirow{2}{*}{$\mathrm{C}^{\prime}$} & 1.390 & 10.4 & 51.3 & 4.3 & 23 & \multirow{8}{*}{2.168} \\
\hline & 1.296 & 6.1 & 58.3 & 0.8 & 23 & \\
\hline \multirow{2}{*}{$A^{\prime} C^{\prime}$} & 2.084 & 47.8 & 18.2 & 1 & 23 & \\
\hline & 1.505 & 27 & 24.3 & 5.2 & 23 & \\
\hline \multirow{2}{*}{$A^{\prime} B^{\prime} C^{\prime}$} & 1.390 & 15.7 & 25.9 & 10.2 & 23 & \\
\hline & 1.162 & 14.6 & 36.6 & 19.5 & 23 & \\
\hline \multirow{2}{*}{$\mathbf{M}$} & 0.727 & 0 & 15.4 & 15.4 & 3 & \\
\hline & 0.455 & 0 & 38.5 & 15.3 & 3 & \\
\hline
\end{tabular}


TABLE 7o

Summarizing the data contained in table $7 a$ and $b$, for the time from January 12,1921, to $\operatorname{March} 7,1921$

\begin{tabular}{|c|c|c|c|c|c|}
\hline FOOD & $\begin{array}{c}\text { AYERAGE } \\
\text { NUMBER DAILY } \\
\text { DIVIBIONS }\end{array}$ & $\begin{array}{l}\text { PER GENT HIGH } \\
\text { DIVIBIONS }\end{array}$ & $\begin{array}{l}\text { PER CENT LOW } \\
\text { DIVIBIONB }\end{array}$ & $\begin{array}{c}\text { PER CENT OF } \\
\text { DEATH }\end{array}$ & $\begin{array}{c}\text { NUMBER OF } \\
\text { DAYS }\end{array}$ \\
\hline \multirow{2}{*}{$\mathrm{C}^{\prime}$} & 1.094 & 13.5 & 41.7 & 6 & 43 \\
\hline & 1.399 & 32.4 & 34.3 & 2 & 43 \\
\hline \multirow{2}{*}{$\mathrm{A}^{\prime} \mathrm{C}^{\prime}$} & 1.591 & 41.5 & 25.1 & 3.1 & 43 \\
\hline & 1.832 & 44.4 & 18.5 & 7.6 & 43 \\
\hline \multirow{2}{*}{$A^{\prime} B^{\prime} C^{\prime}$} & 1.234 & 23.9 & 27.5 & 6.7 & 44 \\
\hline & 1.916 & 45.7 & 27.3 & 9.6 & 44 \\
\hline \multirow{2}{*}{ M } & 0.755 & 9.1 & 19.7 & 31.8 & 9 \\
\hline & 0.595 & 3 & 27 & 37 & 9 \\
\hline
\end{tabular}

below that for those in the hay infusion. That this depression was not due to the changed medium is shown by the significance factor for $\mathrm{A}^{\prime} \mathrm{C}^{\prime}$, the only mixture in which the depression appeared to be at all marked.

When the data for the two observation periods are combined, it is seen that on the whole this change in medium was without significant effect. In general it may be said that changes in medium which were tried had no appreciable effect over a considerable time. The only result of change in medium of any importance was that of a slight transitory stimulation of the metabolism in animals changed to the moneywort infusion.

4. Change in medium accompanied by change in food. In order to determine whether a change in medium would produce an effect upon the metabolism of Paramecium if the food was changed at the same time, animals were washed and placed in 0.1 per cent standard timothy hay infusion and in 0.1 per cent moneywort infusion with the bacteria $J, K, L$ and the mixtures $\mathrm{JK}, \mathrm{JL}, \mathrm{KL}$, and JKL as food. The culture $\mathrm{C}^{\prime}$ was used as control. It was found that the animals in the moneywort infusion did not show any significant increase in rate of metabolism, but the duration of life in the moneywort was in most cases slightly longer. In the hay infusion none of the animals fed with the 
bacteria $\mathrm{J}, \mathrm{K}, \mathrm{L}$, or their combinations, lived over six days, whereas many of those in the moneywort with the same food lived seven days. There was very little effect which could be ascribed to the change in medium, but the increased length of life mentioned may indicate a slight tendency of the moneywort to stimulate. However, in case this was so, the effect was not great enough to overcome the unfavorable nature of the bacterial food.

This experiment indicates that a change of medium in the presence of a food known to be unsatisfactory does not so affect the animals that they are able to utilize such food for any length of time. It would seem, therefore, that whereas the stimulating effect of a changed medium may be an aid in reviving cultures of Paramecium which are not in a thriving condition, the nature of the food is at least as important, and if this be unsuited to the requirements of the animal, no amount of artificial stimulation by altering the medium will prevent the death of such cultures.

5. The effect of sterile media. In order to determine whether the results obtained by feeding certain bacteria which did not support active metabolism in Paramecium were due to the toxic action of such bacteria or merely to the fact that they were for some reason not utilizable for food, certain individuals were thoroughly washed and placed in sterile media. The average length of life in hay infusion was 2.15 days, in uncured swamphay infusion, 2.54 days, and in moneywort infusion, 1.72 days. The maximum duration of life for animals in the first infusion was 4 days, for those in the second, 5 , and for those in the moneywort, 4 days. The minimum duration of life in all three infusions was the same-less than twenty-four hours. Five lines were tested in each case, and controls carried in $\mathrm{C}^{\prime}$ during this time showed the normal rate of metabolism for animals fed upon this organism.

These tests show that Paramecium aurelia will not live for any length of time in sterile media of the type ordinarily used in the laboratory. It is, therefore, to be assumed that the failure of the animals in the preliminary experiments to live in pure or mixed cultures of the bacteria used, was due in most cases to starvation, 
rather than to any toxicity of the bacteria used for food. In such cases as the cultures $\mathrm{L}^{\prime}$ and $\mathrm{K}^{\prime} \mathrm{L}^{\prime}$, however, it is very probable that the bacteria were toxic, since all Paramecia died within twenty-four hours.

\section{HISTORICAL AND DISCUSSION}

Whatever the title of the article or scope of the investigation, all who have worked with Paramecium have been concerned directly or indirectly with some phase of the life-history of this animal. Earlier workers did not conceive the complexity of function and behavior revealed by later studies of its metabolic processes. The sum total of these results reveals a striking similarity to the vital processes of many-celled organisms. The food of an animal is not the least important factor in determining its behavior, yet this has sometimes been ignored, sometimes obscured by too great emphasis of other factors by workers with Paramecium, and still remains to be clearly understood.

The reason for this neglect lies in the fact that since the food of Paramecium consists mainly of bacteria, any study of this factor must necessarily overlap the field of bacteriology. Accordingly, the zoologist has left it alone almost completely, either because of lack of technical skill or because of hesitation to enter unknown territory. Hargitt and Fray ('17) have devised a technic which makes possible the study of the relationship of Paramecium to food. The technic of getting pure cultures of bacteria is the only part of the work essentially new to the protozoologist, and this can easily be learned.

One of the most striking things met with in reading the literature is that the earliest worker to apply experimental methods to the study of Paramecium (Maupas, '88) had possibly a clearer idea of the importance of food than any who followed him until a few years ago. He says: "Possibly the use of Pasteur's methods for culturing bacteria would prove to be more suited to the needs of the Ciliates, but I have never made any attempt in this direction." It seems strange that this very pertinent suggestion should have been so long overlooked, but again it may be that the technical difficulties of obtaining such cultures discouraged 
workers from entering this field and forced them to be content with more or less general methods of food control.

Meissner ('88) was one of the first to investigate the food habits of Protozoa. His experiments dealt with the digestibility of the various types of food, such as starch grains, oil drops, and particles of albumen. His work is of importance in demonstrating that the Protozoa are not essentially unlike the Metazoa in their power to utilize food. Moreover, Meissner showed that not all types of food are digested with equal ease, and some not at all. These findings are of significance in suggesting that variations in digestibility may exist in the normal food of these animals which are of importance when one is attempting to study their behavior.

Environmental factors other than food have received the greater amount of attention of investigators of the Infusoria. Of such factors, the nature of the medium has been perhaps too much emphasized. That the medium is important, there can be no doubt, but if it is of such a nature as to fulfill the osmotic requirements of animals living in it, and to furnish the proper salt content, it would seem that its importance, as far as Paramecium is concerned, lies in its ability to furnish a proper food for the bacteria upon which this animal feeds. Calkins at first ('02 a) thought of the medium as being of main importance, but he soon came to appreciate the relation of bacteria ('02 b). His statement that B. subtilis was the chief food of his Paramecia is probably not justified. We now know that the variety of bacteria living in an ordinary hay infusion is not confined to a single group. Moreover, bacteriologists have subdivided the group of bacteria known as B. subtilis until it includes a large number of forms. Not all of these will support the life of Paramecium, as is shown by a comparison of my results with those of Hargitt and Fray ('17). Calkins was careful to sterilize his media by heating to $90^{\circ}$, but we now know that this temperature is not sufficient to kill many spores. No attempt was made to exclude airborne bacteria which he assumed furnished the greater part of the bacterial food. He may, therefore, have been using an infusion in which deleterious bacteria came to predominate. 
Woodruff ('08) was led to believe that the death of Calkins' animals might have been due to too constant a medium, and accordingly began the cultivation of Paramecium in what he termed a 'varied medium.' He believed that by collecting material at random, he would provide infusions which would more nearly approximate the natural environment of this animal than a constant medium of hay infusion. The conclusion of the procedure was truly remarkable, resulting as it did in the continuing of a single line for several years without a conjugation and a very complete analysis of the life-history.

Later, Woodruff and Baitsell ('11 a) were successful in cultivating Paramecium in a constant medium of beef extract. This work established that mere constancy of medium, provided the fluid used was suitable, did not interfere with the normal course of the life-history of the animal. A constant medium did as well as one which was continually varied.

None of these investigators were working with a closely controlled food. They were, therefore, continually dealing with an important unknown factor. With a known food it is possible to test further the effect of medium upon Paramecium. Two types other than the 0.1 per cent standard timothy hay infusion were used in this work. The infusion made with uncured swamp hay differed from that made with cured timothy hay in that it was prepared from a mixture of grasses which had grown in a swampy lowland district, and was presumably different chemically from the standard infusion. The moneywort differed even more. It was uncured when used, was extremely succulent to start with, and much richer in cell sap than either type of grass. The method used in preparing these infusions was the same, so that gram for gram, equal concentrations were used. The result showed that there was no significant difference in effect of the two grass infusions. The moneywort tended to have a slight stimulating effect for a short time, as shown in the case of $\mathrm{A}^{\prime} \mathrm{B}^{\prime} \mathrm{C}^{\prime}$, and in the fact that when used with such unfavorable foods as $\mathrm{J}, \mathrm{K}$, and $\mathrm{L}$, the duration of life of the animals was somewhat greater than in the standard hay infusion. 
Since the animals fed with $\mathrm{C}^{\prime}, \mathrm{A}^{\prime} \mathrm{C}^{\prime}$, and $\mathrm{A}^{\prime} \mathrm{B}^{\prime} \mathrm{C}^{\prime}$ showed no tendency toward diminished vigor for a period of more than six months in the standard hay infusion, it is possible that the diverse results obtained by Woodruff and Calkins may have been due to fundamental differences in the bacterial content of their infusions rather than to the nature of the media or to the old age of the Paramecia. May it not be that the hay infusion is not so well suited to the maintenance of a favorable mixture of bacteria as is beef extract, and that this accounts for Woodruff's results with this medium? Granted that substances do occur in media which are capable of stimulating Paramecia for a time, is it not more likely that the most important factor in the environment is food?

The full importance of food in the behavior of Paramecium was first recognized by Jennings ('08). He not only recognized that cultural conditions should be identical for different series of animals, but he took special precautions to make them so. He realized that the nature of the bacteria in a given culture was very important, for he says: "It is not sufficient to attend merely to the basic fluid, the bacteria in the culture must be the same." His methods were not directed toward a determination of the exact nature of this food, and he was probably correct in maintaining that if precautions were taken as to the method of making cultures, frequent changes of the animals, and the like, a reasonably constant mixture of bacteria would be obtained, in which enough favorable types would be present to effect a normal metabolism in the animals observed.

The first account of which we have record of feeding Paramecium with a particular bacterium is that of Popoff ('10). He speaks of feeding Paramecium caudatum with cultures of $\mathrm{B}$. proteus mirabilis grown upon potato. Popoff's attention was centered upon the effect of various media on cells. In this case the medium used was ammonia-rich water. He supposed that the food was uniform, but makes no mention of having freed the animals of other bacteria. These Paramecia lived but a few days, and their death was attributed by Popoff to the nature of the medium. Since my work has shown that Paramecium aurelia 
will not live upon B. proteus, it would seem that Popoff's results may have been due to the effect of unfavorable bacterial food rather than the result of an unfavorable medium.

Any experiments dealing with feeding Protozoa pure cultures of bacteria necessarily involve a special technique. It is, however, not diff.cult for the protozoologist to master. Hargitt and Fray ('17) were the first to devise a method for rendering Paramecium bacteria-free, which is very simple and involves no new method of handling the animals. All that is necessary is to have absolutely sterile apparatus and media. Their method consisted in a thorough washing of the animals in several changes of sterile water. The bacteriological tests for controlling cultures in the progress of the work are of the simplest, and with the prepared media now on the market, take little more time than does the making of ordinary hay infusions. In my experiments I have so shortened the method described by Hargitt and Fray that it is possible to carry a very large number of cultures, and my work has shown that with care as to the sterility of all apparatus, one need not fear contamination for some time. This reduces the amount of washing necessary to a minimum - an important factor in economy of time. It would seem, therefore, that there should be no technical obstacles in the way of further investigations concerning food, and that much of the work now under way regarding the effect of glandular extracts and vitamines on the Protozoa might be made more exact by the use of these methods.

The method of making control cultures containing chance mixtures of bacteria is important. Jennings ('08) describes his method for keeping the mixture of bacteria constant. He took Paramecia from vigorous stock cultures and washed them in a large amount of culture fluid. Since the animals were from different infusions, a very representative mixture of bacteria was obtained in the washing fluid. This was used to seed the cultures in which he wished to grow pure lines of Paramecium. By doing this every few days he was able to keep the bacterial content of his cultures at an optimum efficiency as to food. It seemed to me that a chance mixture even more reliable than this 
might be had if sterile media were inoculated every day with fresh hay, and the cultures obtained used when twenty-four hours old. Experience demonstrated that this method is not reliable. Cultures prepared in this way failed to support the life of Paramecium after a period of four months. Since bacteria are known to vary considerably in their resistance to drying, it is very probable that in the method used, I was actually dealing with a progressively changing bacterial content rather than a fairly constant one, as I at the time supposed. It is, therefore, probable that some such method as described by Jennings is to be preferred for keeping Paramecium in vigorous condition upon a chance mixture of bacteria. It is possible that the determination and selection of the predominant bacteria in an infusion by pouring agar plates every day or two, and seeding infusions with predominating colonies thus obtained, without resorting to first growing them in pure culture, might give satisfactory mixtures. This method is, however, open to objection. It is at the best tedious and more time-consuming than the familiar way. Moreover, one is not sure that all types of bacteria found in infusions grow equally well on the ordinary media. Considerable study would be necessary to determine this, and additional time consumed in finding a suitable medium for the growth of all types of bacteria.

The rate of fission is our main index of the metabolic condition of Paramecium. Calkins ('02 a) introduced the method now in use of taking the average division rate for a given number of days as the basis for conclusions regarding the behavior of this infusorian. The number of days chosen in computing the averages. is arbitrary and varied with different investigators. Calkins preferred the ten-day interval. Woodruff used the five-day interval in his investigations. Since, in dealing with the effect of known food, it has seemed desirable to have a record of all fluctuations possible and avoid undue error, a three-day interval was chosen for averaging division rates in this study.

Although it is true that the division rate is the only visible index of the progress of metabolism in Paramecium, and it must serve as the basis for all data bearing on the subject, the phe- 
nomena indicated by the actual rate of division may be expressed in other ways, such as the percentage of high divisions above the mean rate for a given period, percentage of divisions below this mean, and the percentage of deaths. It is believed that such expressions of the activities of the animals are helpful in interpreting their reaction to food. These percentages have been computed and are included in the tables.

One of the newer methods in biometry is the determination of what I have elsewhere termed the 'significance factor.' I have used this term as being less clumsy than any phrase describing the mathematical processes involved, believing that its meaning is as clear as a longer expression. Gross ('20) and MacDowell ('21) have used this method in interpreting physiological results, but, so far as I am aware, it has not previously been used in experimental work with the Protozoa. The use of the significance factor has proved to be the most helpful of any instrument employed in interpreting the facts. It has been possible by its use to decide as to the relative value of different foods or the effects of changes in medium. Division rate alone, even when aided by percentages of high divisions and the like, fails to reveal the entire truth in such cases. For instance, in dealing with changes in medium, the conclusion from an inspection of these data would be that a moneywort infusion was stimulating when first used in all the lines tested. Determination of the significance factor reveals that the only real evidence of acceleration of metabolism was in the case of the mixture $\mathrm{A}^{\prime} \mathrm{B}^{\prime} \mathrm{C}^{\prime}$. We may state, therefore, that although the division rate is the truest index of the metabolism we have yet found for the Protozoa, the interpretation of its meaning is greatly helped by other indices, especially by the use of the 'significance factor,' which at once enables one to settle any doubt as to the trend of the metabolism as expressed by the rate of division.

Under normal conditions Paramecium feeds mainly upon bacteria. The enormous variety of bacteria in infusions makes it possible for this animal to obtain adequate food under natural conditions. However, since Paramecium has no choice as to the type of food, but must ingest whatever comes in its way, it is 
entirely unprotected against deleterious bacteria if these predominate in infusions in which Paramecium is living. The animals may die from starvation in the midst of an abundance of unavailable food, or from poisoning should these bacteria be toxic.

The lack of exact knowledge concerning the characteristics of saprophytic bacteria is a great handicap in undertaking the study of any bacterial mixture serving as food for Paramecium. Hargitt and Fray ('17) found it impossible to identify adequately the organisms with which they worked. Miss Watt and I found the same difficulty in the course of this investigation. I have included cultural characteristics of the organisms used in these experiments with the idea that they might be of some slight help to anyone desiring to undertake similar work, but there is great need for a thorough investigation of the saprophytic bacteria. Until such a study shall have been made, it is desirable that any satisfactory cultures which may be discovered shall be carefully kept and made available to any investigators who wish to use them. The cultures $\mathrm{A}^{\prime}, \mathrm{B}^{\prime}$, and $\mathrm{C}^{\prime}$ are being maintained, and subcultures will be given to those who desire them.

For ordinary routine work, a satisfactory chance mixture maintained at a high state of eff.ciency is to be preferred to an artificial mixture such as used in this investigation. The behavior of animals fed with $M$ during the first month amply demonstrates this, for this mixture was superior to the artificial ones during this period. However, if one is investigating the behavior of Paramecium with great care, a known bacterial content is necessary in infusions. Deleterious bacteria certainly lower the rate of metabolism or cause an undue percentage of deaths and so modify normal metabolism as to greatly influence the interpretation of results.

A varied diet is natural for most animals. Although a given environment may be normal for a particular organism, it is not necessarily one in which the optimum of metabolism can be maintained. Variety of food seems to produce an optimum metabolic rate in all cases investigated, largely because no one type of food has been found which combines all the factors neces- 
sary to maintain this rate. The question arises, does this generalization hold true for the Protozoa? Will Paramecium thrive upon a single type of food, as illustrated by a pure culture of a bacterium, or is a mixed food better for this animal? The fact that Paramecia were able to live upon the streptothrix $\mathrm{C}^{\prime}$ for a period of nine months, when the line was discontinued, would seem to indicate that it is possible for them to live upon a single article of diet. Moreover, in the case described, the metabolic rate was more uniform than with any food save the chance mixture during the first month. The division rate was not so high among animals fed with $\mathrm{C}^{\prime}$ as with the unknown mixture before it failed, or the mixtures $\mathrm{A}^{\prime} \mathrm{C}^{\prime}$ and $\mathrm{A}^{\prime} \mathrm{B}^{\prime} \mathrm{C}^{\prime}$. That such organisms as $\mathrm{C}^{\prime}$, which are capable of supporting the life of Paramecium when fed in pure culture, are not numerous is also indicated. Of the nine cultures of bacteria isolated from infusions and tested, only $\mathrm{C}^{\prime}$ could be so used. It is also true that satisfactory mixtures of known bacteria are hard to find. Two only were discovered out of twelve tested. There is no question but that the method used in this work, and by Hargitt and Fray, is not suitable for providing a thoroughly efficient food, but on the other hand it is the only one yet devised whereby the food can be adequately controlled and known types of bacteria included. These bacteria can be determined only by long and tedious tests, and they must first be obtained in pure culture if the food is to be adequately controlled.

Pure cultures of bacteria usually fail to support the life of Paramecium. This failure may be due to one of two reasons. Paramecium may not be able to digest them and so utilize their contained energy, or else the bacteria may contain or excrete substances which are toxic to this animal. In the first instance the bacteria are ingested, but are not digested. The animal starves as it would in a sterile medium. In the second case death comes more quickly.

Khainsky ('10) undertook to study the relationship between the structure and the physiological state in Paramecium caudatum. He studied the course of the food vacuole and the changes occurring within it by the use of vital stains. It is possible that 
this technique might prove useful in testing the food value of particular bacteria for Paramecium.

The question of toxicity is more complex. In the account of the preliminary experiments of this study, 100 per cent of deaths occurred the first twenty-four hours among animals fed with $L^{\prime}$ and $\mathrm{K}^{\prime} \mathrm{L}^{\prime}$. A wholesale mortality such as this would lead one to suspect that the bacterium $L^{\prime}$ was toxic for Paramecium. Yet, when it was combined with $\mathbf{J}^{\prime}$, itself not a satisfactory food, immediate death did not result. Phenomena such as these need further investigation.

The evidence presented in this paper seems to show that mixtures of bacteria furnish the most satisfactory food for Paramecium. Of all the mixtures tried, the chance mixture $\mathrm{M}$ seems to have been the best, could it have been maintained at an optimum of efficiency. The objection to the use of such a mixture in certain types of experimental work is that its exact content is unknown and is subject to daily variation. A mixture such as $\mathrm{A}^{\prime} \mathrm{C}^{\prime}$, when studied with regard to the division rate and significance factor, is found to be so nearly the equal of the chance mixture during a long period of time, that it may be said to be on the whole as advantageous. It possesses the advantage, moreover, of being known and subject to control.

Mention has been made of the stimulating action of mixed cultures of bacteria as contrasted with pure cultures. The word stimulating is not used here in the same sense as in the account of the effect of change in medium. In this latter instance, any acceleration of metabolism noted is probably due to the action of some chemical constituent of the medium less complex than a food. Mixing foods may cause an acceleration of metabolism simply because more energy becomes available from an outside source, whereas the effect of a chemical stimulant is to release energy locked up within the organism. The increase in metabolic rate as a result of combining pure cultures of bacteria has been the usual experience during this work. Frequent as it has been, however, but two instances, $\mathrm{A}^{\prime} \mathrm{C}^{\prime}$ and $\mathrm{A}^{\prime} \mathrm{B}^{\prime} \mathrm{C}^{\prime}$, were observed where this acceleration of metabolism continued for any great time. 
Woodruff and Erdmann ('14) showed that what they describe as rhythms in Paramecium are due to the internal reorganization of endomixis. The study of Paramecium with reference to food seems to show that minor fluctuations occur in the course of rhythms which, like these latter, are largely independent of environmental conditions. Such fluctuations have been noted by others, but have been attributed to such unknown factors as variation in food or medium. In my experiments food and medium were as exactly controlled as possible. All the organisms were subjected to the laboratory temperature, but, as has been pointed out, since these fluctuations took place when there was little change in the temperature, it would appear that this factor had little to do with their occurrence. More carefully controlled experiments are necessary to determine this. There appear, however, to be fluctuations in the metabolism not directly connected with the rhythms of endomixis, but, like them, due to some intrinsic characteristic of the protoplasm. These fluctuations occur in all cultures irrespective of changes in food or medium and do not appear to be directly due to environmental factors, but rather to be manifestations of protoplasmic changes. This subject needs careful investigation before definite conclusions can be drawn.

Having determined that mixtures of bacteria are more satisfactory than pure cultures, one is led to inquire if such a mixture should be kept constant. Such experiments as were performed in testing the effect of change of food showed that under the conditions obtaining, change of food was usually accompanied by so much disturbance in the metabolism that no marked increase in division rate resulted, and that with these mixtures at least constancy of diet was preferable to change. This result with a known food supports the contention of workers with chance mixtures, namely, that every effort should be made toward maintaining a uniform bacterial content in media used for growing Paramecium.

The behavior of Paramecium in sterile media is of interest for two reasons. It demonstrates that these animals are incapable of utilizing for food any substances which may be dissolved in 
such a medium. For this reason, it is valuable in testing the availability of various bacteria for food. If Paramecia live no longer, or but little longer than in sterile medium, we are justified in assuming that these organisms are unsuitable food; that their energy content is unavailable. Since it has been demonstrated that Paramecium does not utilize the substances dissolved in sterile media of the sort ordinarily used in the laboratory, it would seem that Peters' ('20) contention that Protozoa are capable of saprophytic existence needs further investigation. His experiments dealt with the growth of Colpidium in a sterile synthetic medium very different from hay infusion. Colpidium encysts, and so has a means of becoming adjusted to marked environmental change. It would seem, therefore, that Paramecium or some other non-encysting protozoan should be tested in this synthetic medium before generalizations can be made regarding the ability of Protozoa to live as saprophytes.

\section{SUMMARY}

The study of the behavior of Paramecium aurelia when fed with known bacteria shows that it is perfectly feasible to control the bacterial content of a medium and that the technique required is not too laborious. In studying such conditions, it has been found that, in addition to the rate of fission, a consideration of the percentages of high and low divisions and the death rate is of value. The application of the significance factor to data of this type has proved exceedingly useful, making possible decisions with regard to effects of food and media which could not otherwise have been reached.

The contention of Hargitt and Fray that pure cultures of bacteria are as a rule unsatisfactory food for Paramecium has been sustained in this work. Moreover, in the single instance in which a pure culture could be used over a long period, the metabolic rate was consistently lower than that of any mixture employed. Mixtures of bacteria would then appear to be the most satisfactory food for Paramecium. Of all the artificial mixtures tested, but two were found which furnished adequate food over 
a long period of time. These two artificial mixtures were nearly as satisfactory as the usual chance mixture.

When Paramecia are fed with known mixtures of bacteria, it is found that minor fluctuations in division rate occur which are independent of endomixis, and like it do not seem to be greatly influenced by environment. The evidence gathered tends to favor constancy of food rather than frequent change. The influence of ordinary media is practically without effect. Paramecium is unable to utilize food substance dissolved in such media.

\section{LITERATURE CITED}

Calkins, Garx N. 1902 a Studies on the life history of the Protozoa. I. The life history of Paramecium caudatum. Arch. f. Ent-Mech., Bd. 15, S. 139-186.

$1902 \mathrm{~b}$ Studies on the life history of the Protozoa. III. The six hundred and twentieth generation of Paramecium caudatum. Biol. Bull., vol. 3, pp. 192-205.

Chester, F. D. 1914 A manual of determinative bacteriology. The Macmillan Company.

Gillespie, L. J. 1920 Colorimetric determination of the H-ion concentration without buffer mixtures, with special reference to soils. Soil Sci., vol. 9, pp. 115-136.

Gross, A. O. 1920 The feeding habits and chemical sense of Nereis virens Sars. Jour. Exp. Zoöl., vol. 32, pp. 427-442.

HargrtT, G. T., and Fray, W. W. 1917 The growth of Paramecium in pure cultures of bacteria. Jour. Exp. Zoöl., vol. 22, pp. 421-455.

Huntington, E. J. 1918 Handbook of mathematics for engineers. McGraw Hill Book Company.

Jennings, H. S. 1908 Heredity, variation and evolution in Protozoa. III. Proc. Amer. Phil. Soc., vol. 47, pp. 393-546.

1910 What conditions induce conjugation in Paramecium? Jour. Exp. Zö̈l., vol. 9, pp. 279-299.

Khalnsky, A. 1910 Physiologische Untersuchungen über Paramecium caudatum. Biol. Centr., Bd. 30, S. 267-278.

MacDoweli, E. C., AND VICARI, E. M. 1921 Alcoholism and the behavior of white rats. I. The influence of alcoholic grandparents upon maze behavior. Jour. Exp. Zoöl., vol. 33, pp. 209-291.

MAUPAS, E. 1888 Recherches expérimentales sur la multiplication des infusoires ciliés. Arch. de Zoöl. Exp. et Gén., Ser. 2, T.6, pp. 165-277.

Meissner, M. 1888 Beiträge zur Ernähruhgsphysiologie der Protozəen. Zeit. f. Wiss. Zool., Bd. 46, S. 498-516. 
Peters, R. A. 1920 a Nutrition of the Protozoa. The growth of Paramecium in sterile culture medium. Jour. Physiol., vol. 53; Proc. Physiol. Soc., Feb. 21, 1920, cviii.

$1920 \mathrm{~b}$ Nutrition of the Protozoa. 2. Carbon and nitrogen compounds needed for the growth of Paramecium. Jour. Physiol., vol. 54; Proc. Physiol. Soc., Oct. 16, 1920, i.

Popoff, M. 1910 Experimentelle Zellstudien. III. Ueber einige Ursachen der physiologischen Depression der Zelle. Arch. f. Zellf., Bd , 4, S. 1-43.

Winstow, C.-E.A., AND others 1920 The families and genera of the bacteria. Final report of the committee of the Society of American Bacteriologists on characterization and classification of bacterial types. Jour. Bact., vol. 5, pp. 191-229.

Woodnuff, L. L. 1908 The life cycle of Paramecium when subjected to a varied environment. Am. Nat., vol. 42, pp. 520-526.

1911 Evidence on the adaptation of Paramecium to different environments. Biol. Bull., vol. 22, pp. 60-65.

Woodrdfr. L. L., ANd Baitseli, G. A. 1911 The reproduction of Paramecium aurelia in a 'constant culture medium' of beef extract. Jour. Exp. Zoöl., vol. 11, pp. 135-142.

Woodruff, L. L., AND ERdmann, R. 1914 A normal periodic reorganization process without cell fusion in Paramecium. Jour. Exp. Zoöl., vol. 17, pp. 425-518. 